\title{
AREA 2 PHOTO SKID WASTEWATER PIT CORRECTIVE ACTION DECISION DOCUMENT CORRECTIVE ACTION UNIT NO. 332: PART 1 AND CLOSURE REPORT: PART 2
}

DOE Nevada Operations Office

Las Vegas, Nevada

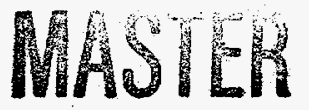

Controlled Copy No.

Revision No.: 0

DISTRIBUTIOY OF THS DOCUMENT IS UNLIVITEL

June 1997 


\section{DISCLAIMER}

This report was prepared as an account of work sponsored by an agency of the United States Government. Neither the United States Government nor any agency thereof, nor any of their employees, makes any warranty, express or implied, of assumes any legal liability or responsibility for the accuracy, completeness, or usefulness of any information, apparatus, product, or process disclosed, or represents that its use would not infringe privately owned rights. Reference herein to any specific commercial product, process, or service by trade name, trademark, manufacturer, or otherwise does not necessarily constitute or imply its endorsement, recommeridation, or favoring by the United States Government or any agency thereof. The views and opinions of authors expressed herein do not necessarily state or reflect those of the United States Government or any agency thereof. 


\section{DISCLAIMER}

Portions of this document may be illegible electronic image products. Images are produced from the best available original document. 


\section{AREA 2 PHOTO SKID WASTEWATER PIT CORRECTIVE ACTION DECISION DOCUMENT CORRECTIVE ACTION UNIT NO. 332: PART 1 \\ AND \\ CLOSURE REPORT: PART 2}

Approved by:

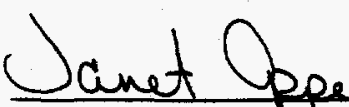

Janet Appenzeller-Wing, Project Aanager, Industrial Sites Subproject

Approved by:

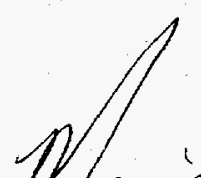

Stephen A. Mellington, Project Manager,<smiles>C1=CCCCC1</smiles>
Nevada Environmental Restoration Project
Date: $6 / 19 / 97$

Date:

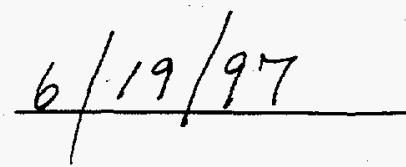




\section{Table of Contents}

List of Figures iii

List of Acronyms and Abbreviations iv

\section{CORRECTIVE ACTION DECISION DOCUMENT}

CORRECTIVE ACTION UNIT NO. 332: PART 1

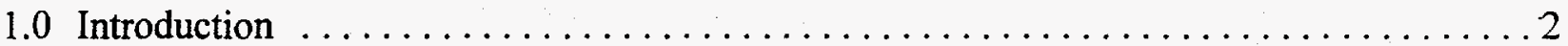

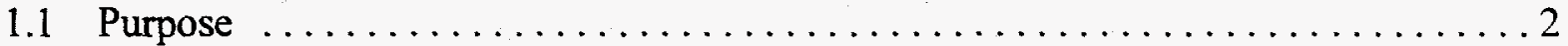

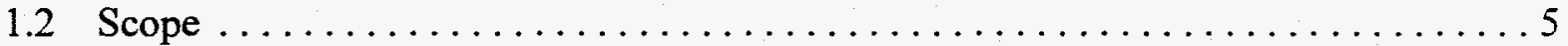

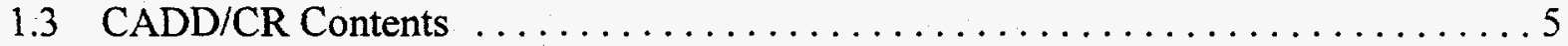

2.0 Corrective Action Investigation Summary $\ldots \ldots \ldots \ldots \ldots \ldots \ldots \ldots \ldots \ldots \ldots \ldots \ldots \ldots \ldots \ldots \ldots \ldots$

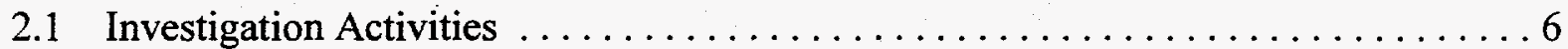

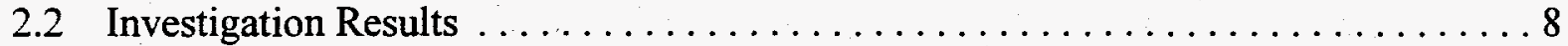

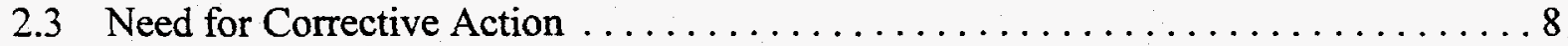

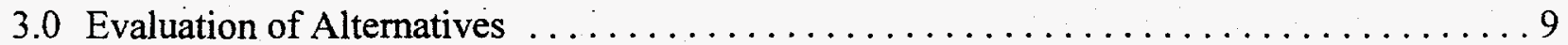

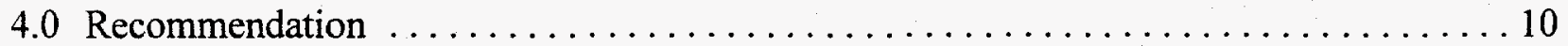

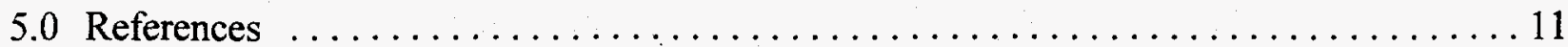




\section{Table of Contents (Continued)}

Appendix A - Area 2 Photo Skid Wastewater Pit Corrective Action Unit No. 332, Nevada Test Site

Attachment 1 - Boring Logs

Appendix B - Document Review Sheet 


\section{List of Figures}

Number

Title

Page

1-1 Location of the Area 2 Photo Skid Wastewater Pit, Nevada Test Site 3

1-2 Photo Skid Wastewater Pit Site Map $\ldots \ldots \ldots \ldots \ldots \ldots \ldots \ldots \ldots \ldots \ldots$

2-1 Site Map for the Wastewater Pit $\ldots \ldots \ldots \ldots \ldots \ldots \ldots \ldots \ldots \ldots \ldots$ 
Area 2 Photo Skid

Contents

Revision: 0

Date: $06 / 20 / 97$

Page iv of iv

List of Acronyms and Abbreviations

$\begin{array}{ll}\text { CADD } & \text { Corrective Action Decision Document } \\ \text { CAIP } & \text { Corrective Action Investigation Plan } \\ \text { CAS } & \text { Corrective Action Site } \\ \text { CAL } & \text { Corrective Action Unit } \\ \mathrm{cm} & \text { Centimeter(s) } \\ \text { COC } & \text { Chemicals) of concern } \\ \text { CR } & \text { Closure Report } \\ \text { DQO } & \text { Data Quality Objectives) } \\ \text { FFACO } & \text { Federal Facility Agreement and Consent Order } \\ \mathrm{ft} & \text { Foot (feet) } \\ \text { in. } & \text { Inch(es) } \\ \text { m } & \text { Meters) } \\ \text { TCLP } & \text { Toxicity Characteristic Leaching Procedure } \\ \text { VOC } & \text { Volatile organic compounds) }\end{array}$




\section{CORRECTIVE ACTION DECISION DOCUMENT CORRECTIVE ACTION UNIT NO. 332: PART 1}




\subsection{Introduction}

This Area 2 Photo Skid Wastewater Pit Corrective Action Decision Document Corrective Action Unit No. 332: Part 1 and Closure Report: Part 2 was prepared for the U.S. Department of Energy's Nevada Environmental Restoration Project. The Corrective Action Decision Document (CADD) and the Closure Report (CR) have been developed to meet the requirements of the Federal Facility Agreement and Consent Order (FFACO, 1996). The CADD and the CR for this Corrective Action Site (CAS) have been combined because sample data collected during the site investigation do not exceed regulatory limits established during the Data Quality Objectives (DQO) process (DOE/NV, 1997). Therefore, per the FFACO and the Corrective Action Investigation Plan: Area 2 Photo Skid No. 16, Corrective Action Unit 332 (DOE/NV, 1997) DQO process, no further action is required at the site.

The Area 2 Photo Skid Wastewater Pit, CAS No. 02-42-03, the only CAS in CAU No. 332, has been identified as a source of unquantified, uncontrolled, and unpermitted wastewater discharge. The Photo Skid was used for photographic processing of film for projects related to weapons testing, using Kodak RA4 and GPX film processing facilities for black and white and color photographs. The CAU is located in Area 2 of the Nevada Test Site, Nye County, Nevada (Figure 1-1).

The CAS consists of one unlined pit which received discharged photographic process wastewater from 1984 to 1991 (DOE/NV, 1997). The outer dimensions of the pit are approximately 30 meters $(\mathrm{m})$ by $30 \mathrm{~m}$ (100 feet [ft] by $100 \mathrm{ft})$, and the pit is approximately $2 \mathrm{~m}(7 \mathrm{ft})$ deep at its lowest (i.e., deepest) point (Figure 1-2). The walls of the pit are steep-sided (25-to 40-degree slopes), and the base is covered with a layer of gravel (i.e., pebbles and cobbles) approximately 92 centimeters (cm) (36 inches [in.]) deep. A 15-cm (6-in.) diameter discharge pipe (constructed of polyvinyl chloride) enters the pit on the northeast side at a point approximately $60 \mathrm{~cm}(2 \mathrm{ft}$ ) above the bottom of the pit floor (DOE/NV, 1997):

\subsection{Purpose}

The purpose of the CADD and the CR is to justify why no corrective action is necessary at the $\mathrm{CAU}$ based on process knowledge and the results of the corrective action investigation and to request closure of the $\mathrm{CAU}$. 


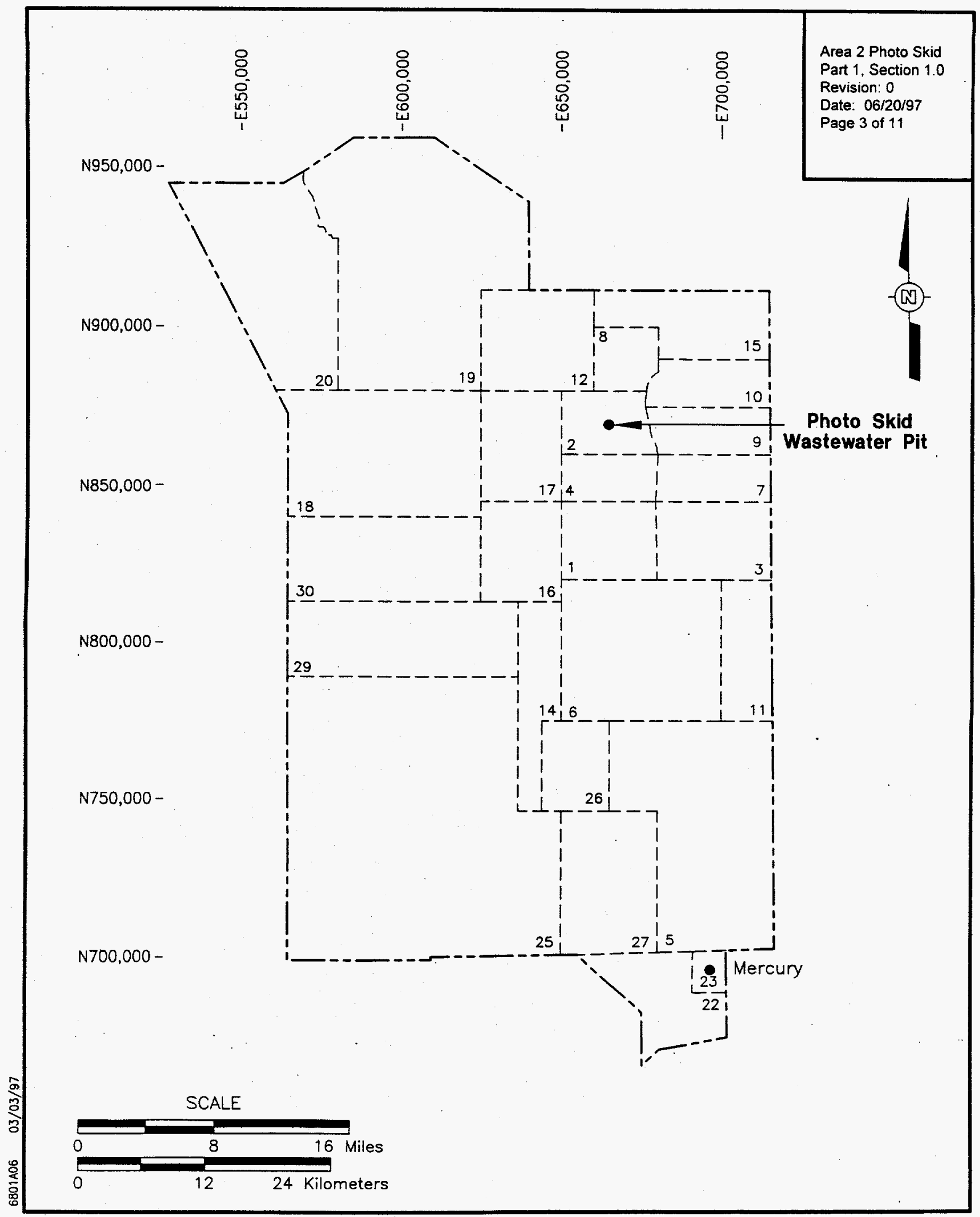

Figure 1-1

Location of the Area 2 Photo Skid Wastewater Pit, Nevada Test Site 


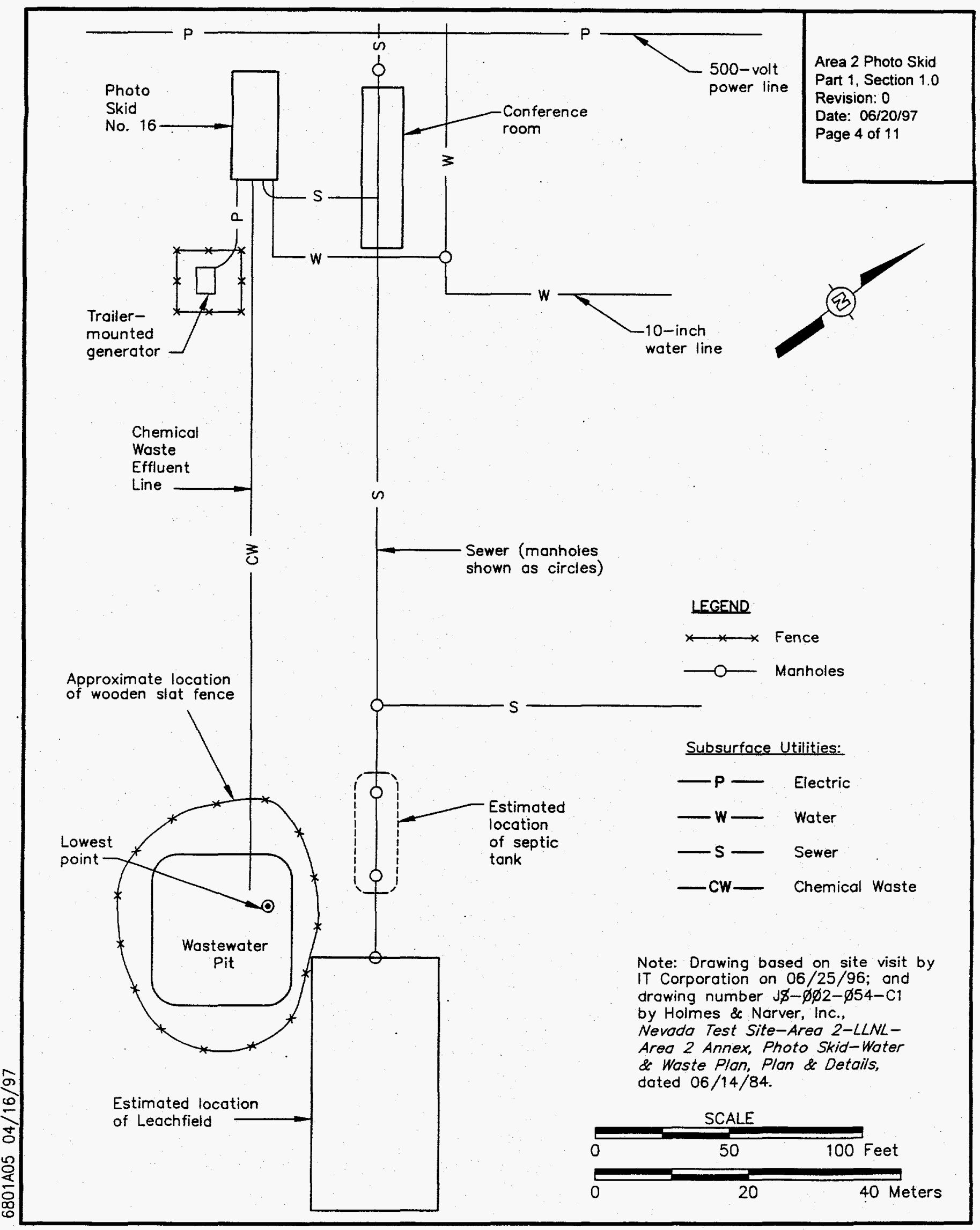

Figure 1-2

Photo Skid Wastewater Pit Site Map 


\subsection{Scope}

The scope of the CADD and the CR is to justify and recommend that no corrective action is required at the Area 2 Photo Skid Wastewater Pit CAU. To achieve this scope, the following actions are required:

- Review the current site conditions, including the nature and extent of contamination.

- Document closure of the CAU.

\section{$1.3 C A D D / C R$ Contents}

This document has been divided into two parts. The first part, the CADD, consists of the following sections:

- Section 1.0 - Introduction

- Summarizes the purpose and scope of the CADD

- Section 2.0 - Corrective Action Investigation Summary

- Provides a brief site background and the historical use of the CAS; summarizes the results of the investigation field activities and the need for corrective action.

- Section 3.0 - Evaluation of Alternatives

- Documents the steps taken in determining a recommended corrective action

- Section 4.0 - Recommendation

- Presents the preferred corrective action and the rationale for its selection

- Section 5.0 - References

- Presents a list of all referenced documents.

- Appendix A - Area 2 Photo Skid Wastewater Pit Corrective Action Investigation Report

The second part of this document, the CR, consists of the following parts:

- Section 1.0 - Introduction

- Summarizes the purpose and scope of the CR

- Section 2.0 - Closure Activities

- Summarizes the closure activities for the CAU 


\subsection{Corrective Action Investigation Summary}

The following sections describe and summarize the results of the corrective action investigation activities conducted at the Area 2 Photo Skid Wastewater Pit CAU.

\subsection{Investigation Activities}

In February 1997, IT Corporation performed a corrective action investigation that consisted of the following activities as set forth in the Corrective Action Investigation Plan (CAIP) (DOE/NV, 1997). Details of the data collection and results are included in the Corrective Action Investigation Report presented in Appendix A.

- Collected one surface soil sample (51 to $61 \mathrm{~cm}$ [20 to 24 in.]) from below the outfall pipe within the wastewater pit

- Drilled four soil borings (two at 10 feet outside the pit and two inside the pit) to a total depth of $5.5 \mathrm{~m}$ (18 ft) below land surface (except for boring B3 which is $4 \mathrm{~m}$ [13 ft] deep) (Figure 2-1)

- Collected four subsurface samples (two from each boring) from the two soil borings (B1 and B2) drilled outside the pit (Appendix A)

- Collected nine subsurface samples (four from boring B4 and five from boring B3) from the two soil borings drilled inside the pit (Appendix A)

- Analyzed environmental and associated quality control samples for volatile organic compounds (VOCs), semivolatile organic compounds, Toxicity Characteristic Leaching Procedure (TCLP) metals, total petroleum hydrocarbon as diesel, general chemistry (i.e., nitrate, nitrite, and sulfate), and gamma spectroscopy

- Assessed the potential downward migration of contaminants through the surrounding soils

- Evaluated the lateral extent of contamination migration (if present) from the wastewater pit

In addition, historical documents, interviews, and process knowledge were used to assist in the identification of potential contamination at the wastewater pit (see Appendix A). 


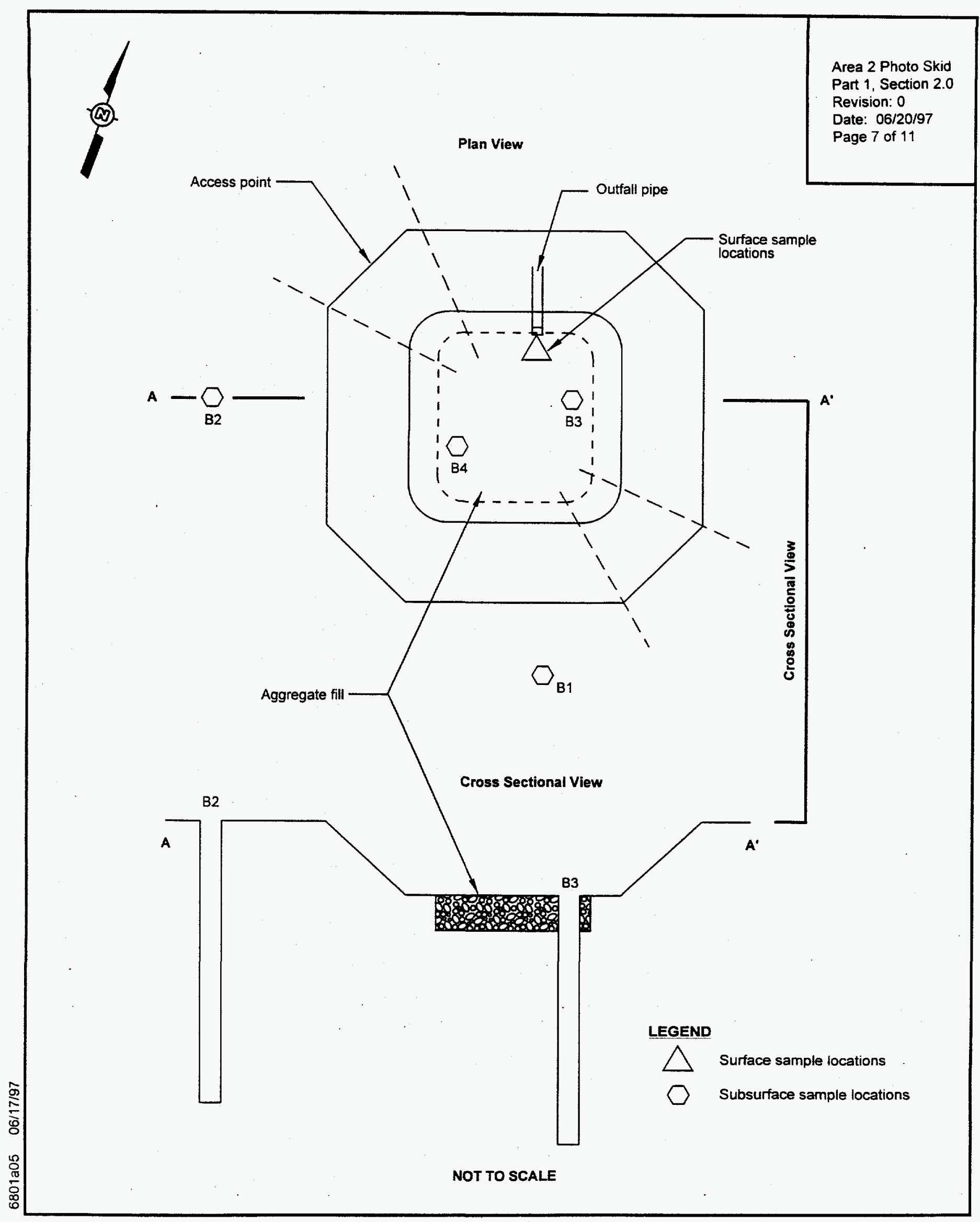

Figure 2-1

Site Map for the Wastewater Pit 


\subsection{Investigation Results}

The corrective action investigation results indicated the following (Appendix A):

- The only VOCs detected were traces of acetone and 2-butanone which were also detected in sample blanks and are considered laboratory contaminants. Chloroform was detected at an estimated value below the method detection limit.

- Semivolatile organic compounds were not detected in any of the samples.

- Sulfate, nitrate as nitrogen, and nitrite as nitrogen were detected in all the soil samples below their associated action level (DOE/NV, 1997). The maximum values were from samples collected at the outfall pipe.

- The TCLP metals (i.e., chromium and lead) were detected in the samples at the outfall pipe at values below action levels (DOE/NV, 1997). All other samples were non-detect for TCLP metals.

- Radionuclides detected in surface samples were all of primordial origin or their decay products. All activity detected was below minimum detected activity (see Appendix A).

\subsection{Need for Corrective Action}

Analytes detected as the result of the corrective action investigation were evaluated to determine the potential chemicals of concern (COCs) for the Area 2 Photo Skid Wastewater Pit.

On the basis of this evaluation, no constituents were identified above applicable regulatory limits (i.e., U.S. Environmental Protection Agency Region LX Preliminary Remediation Goals [EPA, 1996] or the Nevada Test Site Performance Objective for Certification of Nonradioactive Hazardous Waste [BN, 1995]); therefore, no COCs were identified. No actions will be required to address contaminants at the CAU.

Section 3.5.3 of the CAIP states, "If soil concentrations in the vicinity of the wastewater pit are below the action levels listed above, then no further action will be taken" (DOE/NV, 1997). 


\subsection{Evaluation of Alternatives}

No COCs have been identified at the site; therefore, no development or evaluation of corrective action alternatives to address contamination is required. 


\subsection{Recommendation}

Based on the investigation results, no corrective action is required at the Area 2 Photo Skid Wastewater Pit CAU. Consequently, no Corrective Action Plan will be developed, and no closure activities will be conducted. Closure of the site is requested.

While no corrective actions are required, the Photo Skid wastewater pit may present an attractive nuisance. Therefore, for best management practices, it will be backfilled to grade. 


\subsection{References}

BN, see Bechtel Nevada.

Bechtel Nevada. 1995. Nevada Test Site Performance Objective Certification of Nonradioactive Hazardous Waste. Las Vegas, NV.

DOE/NV, see U.S. Department of Energy, Nevada Operations Office.

EPA, see U.S. Environmental Protection Agency.

FFACO, see Federal Facility Agreement and Consent Order.

Federal Facility Agreement and Consent Order of 1996. Agreed to by the Nevada Division of Environmental Protection, the U.S. Department of Energy, and the U.S. Department of Defense.

U.S. Department of Energy, Nevada Operations Office. 1997. Corrective Action Investigation Plan: Area 2 Photo Skid No. 16 Wastewater Pit, Rev. 1. Las Vegas, NV: IT Corporation.

U.S. Environmental Protection Agency. 1996. Region LX Preliminary Remediation Goals (PRGs). San Francisco, CA. 
Area 2 Photo Skid

Part 2

Revision: 0

Date: 06/20/97

Page $i$ of ii 


\section{Table of Contents}

CLOSURE REPORT: PART $2 \ldots \ldots \ldots \ldots \ldots \ldots \ldots \ldots \ldots \ldots \ldots \ldots \ldots \ldots \ldots \ldots$

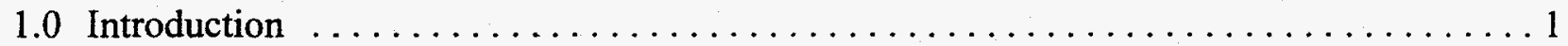

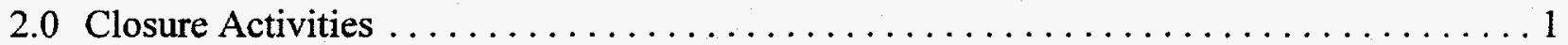

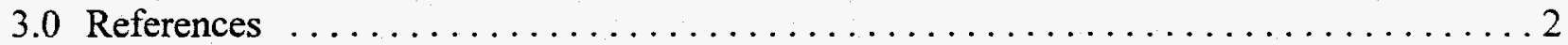




\subsection{Introduction}

This Closure Report for the Area 2 Photo Skid Wastewater Pit (Corrective Action Unit No. 332) was prepared for the U.S. Department of Energy's Nevada Environmental Restoration Project. This Closure Report has been developed to meet the requirements of the Federal Facility Agreement and Consent Order (FFACO, 1996). The site should be clean-closed based on process knowledge and the results of the correction action investigation, which did not identify any chemicals of concern.

\subsection{Closure Activities}

No closure activities are required to address contaminants at this Corrective Action Unit. Section 3.5.3 of the Corrective Action Investigation Plan states, "If soil concentrations in the vicinity of the wastewater pit are below the action levels listed above, then no further action will be taken" (DOE/NV, 1997). Based on this statement and the data collected during the site investigation (as reported in Appendix A of Part I, the Corrective Action Decision Document), no further corrective actions are required at this site; therefore, no Corrective Action Plan is required. This Corrective Action Unit is effectively clean closed.

Because the Photo Skid wastewater pit may present an attractive nuisance, it will be filled with clean soil and leveled as a best management practice.

Upon receipt of the Corrective Action Unit Notice of Completion, the site listing will be transferred to Appendix IV of the Federal Facility Agreement and Consent Order FFACO. No land-use restrictions are required to be placed on the Corrective Action Unit because the investigation showed no evidence of contamination at the site: 
Area 2 Photo Skid

Part 2, Section 3.0

Revision: 0

Date: $06 / 20 / 97$

Page 2 of 2

3.0 References

Federal Facility Agreement and Consent Order of 1996. Agreed to by the Nevada Division of Environmental Protection, the U.S. Department of Energy, and the U.S. Department of Defense.

U.S. Department of Energy, Nevada Operations Office. 1997. Corrective Action Investigation Plan: Area 2 Photo Skid No. 16 Wastewater Pit, Rev. 1. Las Vegas, NV: IT Corporation. 
Appendix A

Area 2 Photo Skid Wastewater Pit Corrective Action Investigation Report Corrective Action Unit No. 332, Nevada Test Site 


\section{Table of Contents}

List of Figures iv

List of Tables $\mathrm{v}$

List of Acronyms and Abbreviations vi

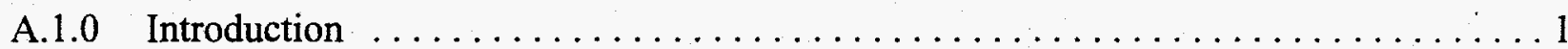

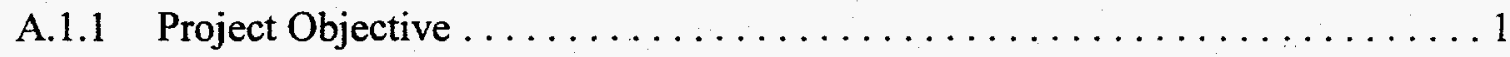

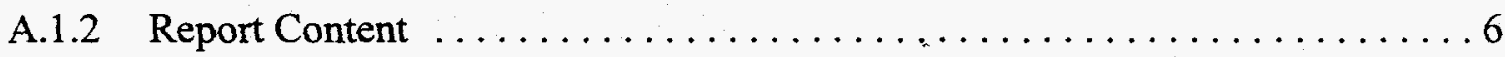

A.2.0 Field Investigation and Sampling Activities $\ldots \ldots \ldots \ldots \ldots \ldots \ldots \ldots$

A.2.1 Site Description and Conditions $\ldots \ldots \ldots \ldots \ldots \ldots \ldots \ldots \ldots$

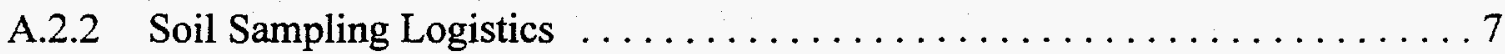

A.2.2.1 Surface Samples . . . . . . . . . . . . . . . . . . . 9

A.2.2.2 Boring Locations $\ldots \ldots \ldots \ldots \ldots \ldots \ldots$

A.2.2.3 Subsurface Sampling $\ldots \ldots \ldots \ldots \ldots \ldots \ldots \ldots \ldots \ldots \ldots \ldots$

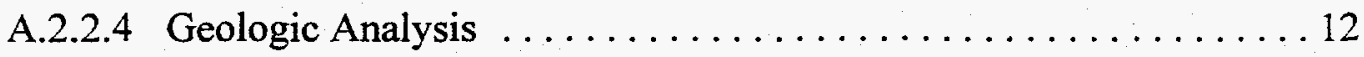

A.2.2.5 Drilling Characteristics and Subsurface Stratigraphy $\ldots \ldots \ldots \ldots 12$

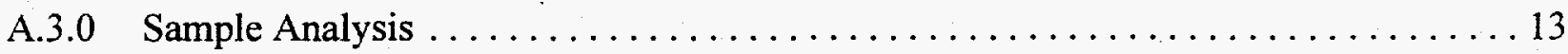

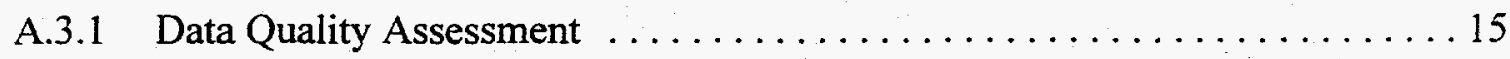

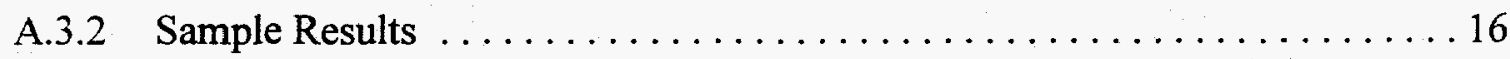

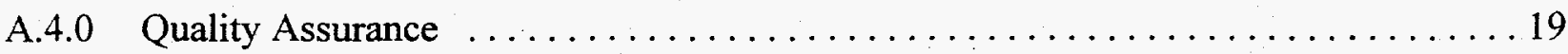

A.4.1 Quality Control Samples . . . . . . . . . . . . . . . . . . 19

A.4.1.1 Field Quality Control Samples ................ 20

A.4.1.2 Laboratory Quality Control Samples ................ 20

A.4.2 Quality Assurance Objectives Measurements ................ 20

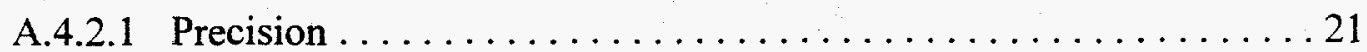

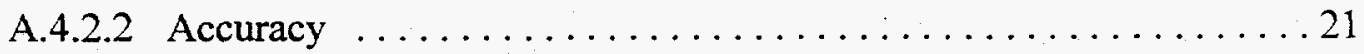

A.4.2.3 Representativeness . . . . . . . . . . . . . . . 24

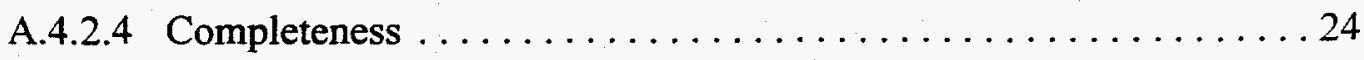

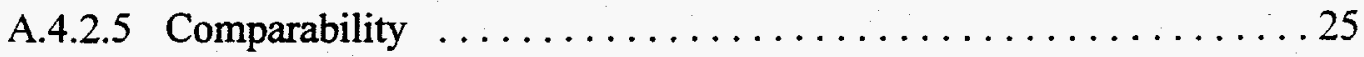




\section{Table of Contents (Continued)}

A.4.3 Field Deficiencies/Nonconformance ................... 25

A.4.4 Laboratory Nonconformances . . . . . . . . . . . . . . . 25

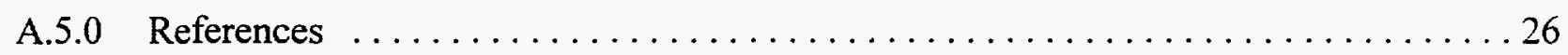

Attachment A-1 - Boring Logs 


\section{List of Figures}

Number

Title

Page

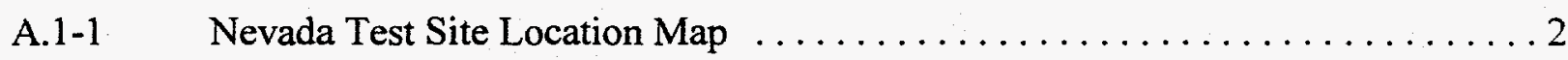

A.1-2 Location of the Area 2 Photo Skid Wastewater Pit, Nevada Test Site ........ 3

A.1-3 Site Map, Area 2 Photo Skid Wastewater Pit, Nevada Test Site $\ldots \ldots \ldots \ldots .4$

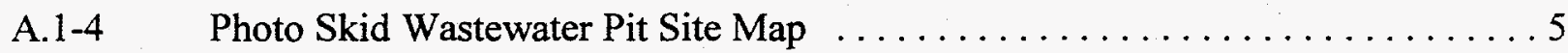

A.2-1 Site Map of the Wastewater Pit $\ldots \ldots \ldots \ldots \ldots \ldots \ldots \ldots \ldots \ldots$

A.2-2 Schematic of Boreholes Drilled at the Wastewater Pit $\ldots \ldots \ldots \ldots \ldots \ldots$ 


\section{List of Tables}

Number

A.3-1 Area 2 Photo Skid Wastewater Pit Soil Samples List

A.3-2 Chemical Analytical Methods Used for Wastewater Pit Investigation Samples .15

A.3-3 Area 2 Photo Skid Wastewater Pit Sample Results - Analytes Detected ...... 17

A.4-1 Area 2 Photo Skid Wastewater Pit Field Quality Control Samples

Collected for Laboratory Analysis

A.4-2 Laboratory Precision Measurements for Area 2 Photo Skid Wastewater Pit

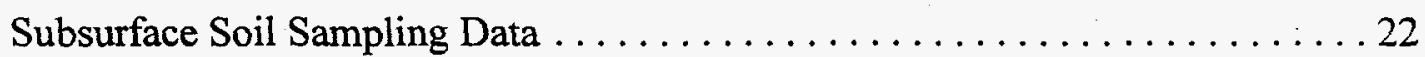

A.4-3 Laboratory Accuracy Measurements for Area 2 Photo Skid Wastewater Pit

Subsurface Soil Sampling Data $\ldots \ldots \ldots \ldots \ldots \ldots \ldots \ldots \ldots \ldots \ldots \ldots \ldots$ 


\section{List of Acronyms and Abbreviations}

bgs Below ground surface

CAIP Corrective Action Investigation Plan

CAS Corrective Action Site(s)

CAU Corrective Action Unit(s)

CFR Code of Federal Regulations

$\mathrm{cm} \quad$ Centimeter(s)

COC Chemical(s) of concern

DOE U.S. Department of Energy

DQO Data Quality Objective(s)

EPA U.S. Environmental Protection Agency

FFACO Federal Facility Agreement and Consent Order

FADL Field Activity Daily Log(s)

$\mathrm{ft} \quad$ Foot (feet)

in. Inch(es)

IT

IT Corporation

LAS Lockheed Analytical Services

m Meter(s)

MCL Maximum contaminant level

$\mathrm{mg} / \mathrm{kg} \quad$ Milligrams per kilogram

$\mathrm{mg} / \mathrm{L} \quad$ Milligram(s) per liter

$\mathrm{N}$

Nitrite/Nitrate

NA

Not applicable

NAC

Nevada Administrative Code

ND

Non-detect

POC

Performance Objective Criteria

QA

Quality assurance

QAPP

Quality Assurance Project Plan

QC

Quality control

RCRA Resource Conservation and Recovery Act

RPD Relative percent difference

SVOC Semivolatile organic compound(s)

TC

Toxicity Characteristic 


\section{List of Acronyms and Abbreviations (Continued)}

TCLP Toxicity Characteristic Leaching Procedure

TPH Total Petroleum Hydrocarbon(s)

UTM Universal Transverse Mercator

VOC Volatile organic compound(s)

$\% \mathrm{R} \quad$ Percent recovery

$\mu \mathrm{g} / \mathrm{L} \quad$ Microgram(s) per liter 


\section{A.1.0 Introduction}

This investigation report represents the implementation of the Corrective Action Investigation Plan (CAIP) (DOE/NV, 1997) for Corrective Action Unit (CAU) No. 332 in accordance with the Federal Facility Agreement and Consent Order (FFACO, 1996) and the Industrial Sites Quality Assurance Project Plan (QAPP) (DOENN, 1996). The CAU No. 332 is comprised of Corrective Action Site (CAS) No. 02-42-03, the Area 2 Photo Skid, which is a wastewater pit that formerly received photographic process wastewater from 1984 to 1991 (DOE/NV, 1997). The CAS is located in Area 2 of the Nevada Test Site (Figures A.1-1, A.1-2, A.1-3, and A.1-4) which is operated by the U.S. Department of Energy (DOE).

\section{A.1.1 Project Objective}

The objective of this project included:

- Collecting data to confirm the presence or absence of contamination.

- Determining the lateral and vertical extent of any contaminants.

- Providing sufficient information to develop closure strategies for the CAU.

- Determining the presence of previously unidentified chemicals of concern (CÖCs).

To meet the objectives, one surface sample was collected, and four boreholes were drilled and sampled to:

- Evaluate the condition of the subsurface sediment and determine if COCs such as chromium, silver, nitrate, nitrite, and sulfate were present above action levels (DOE NV, 1997).

- Assess the potential for migration of the COCs, if present, downward from source points through the surrounding sediment.

- Estimate the lateral extent of contaminant migration (if present) from the Photo Skid.

A surface sample and a duplicate sample were collected from below the outfall pipe within the pit. The samples were collected from a depth of 51 to 61 centimeters $(\mathrm{cm})$ (20 to 24 inches [in.]). 


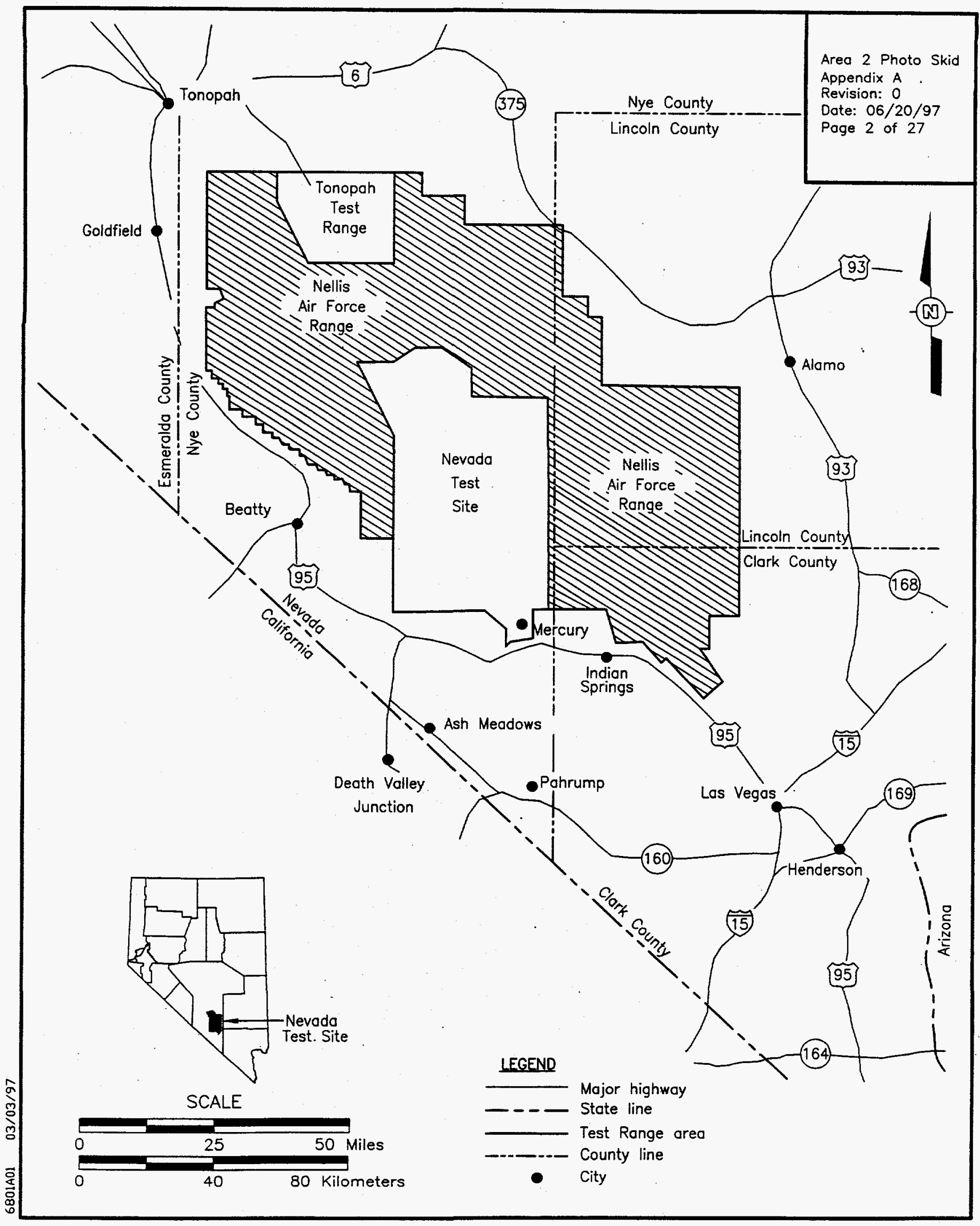

Figure A.1-1

Nevada Test Site Location Map 


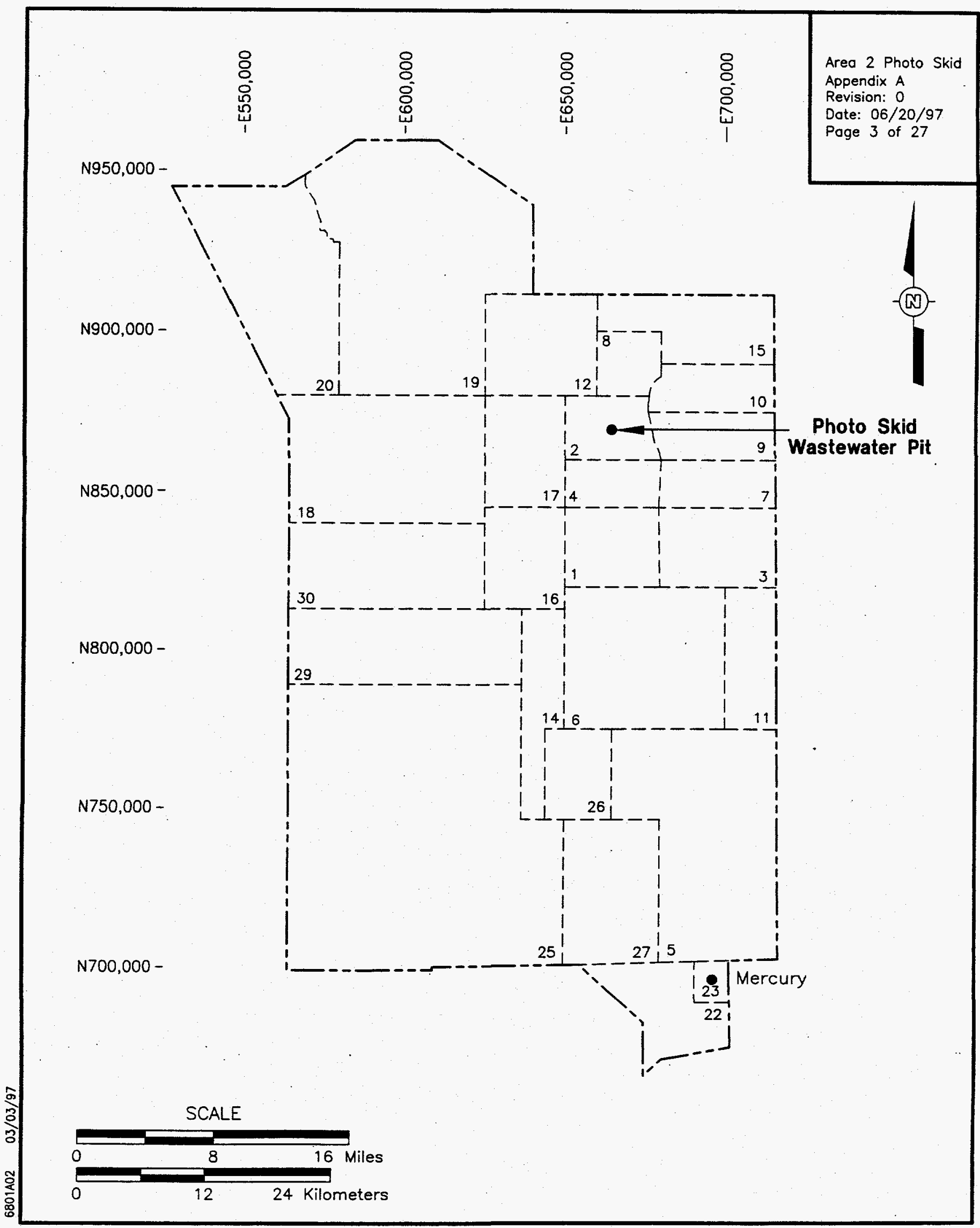

Figure A.1-2

Location of the Area 2 Photo Skid Wastewater Pit, Nevada Test Site 


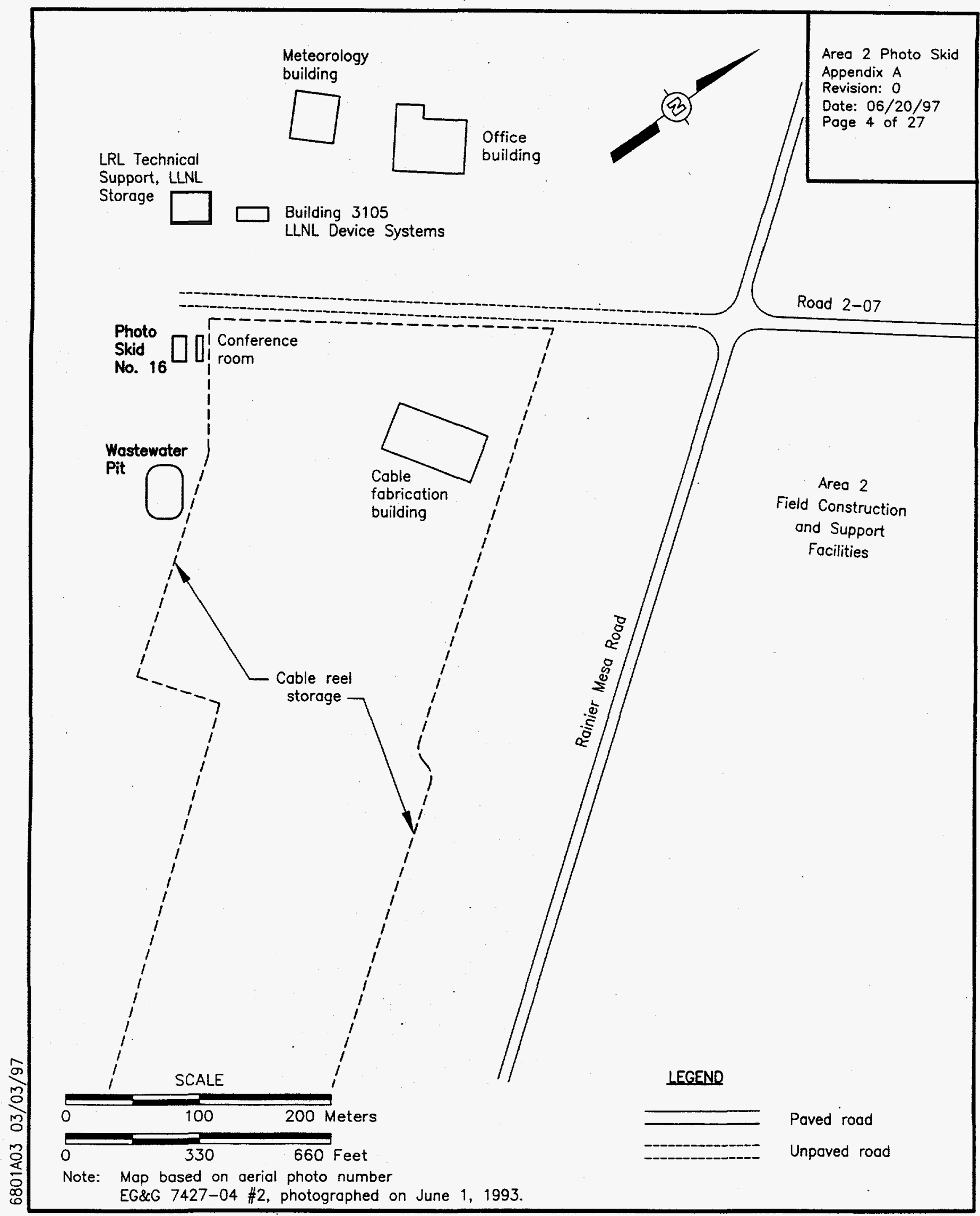

Figure A.1-3

Site Map, Area 2 Photo Skid Wastewater Pit, Nevada Test Site 


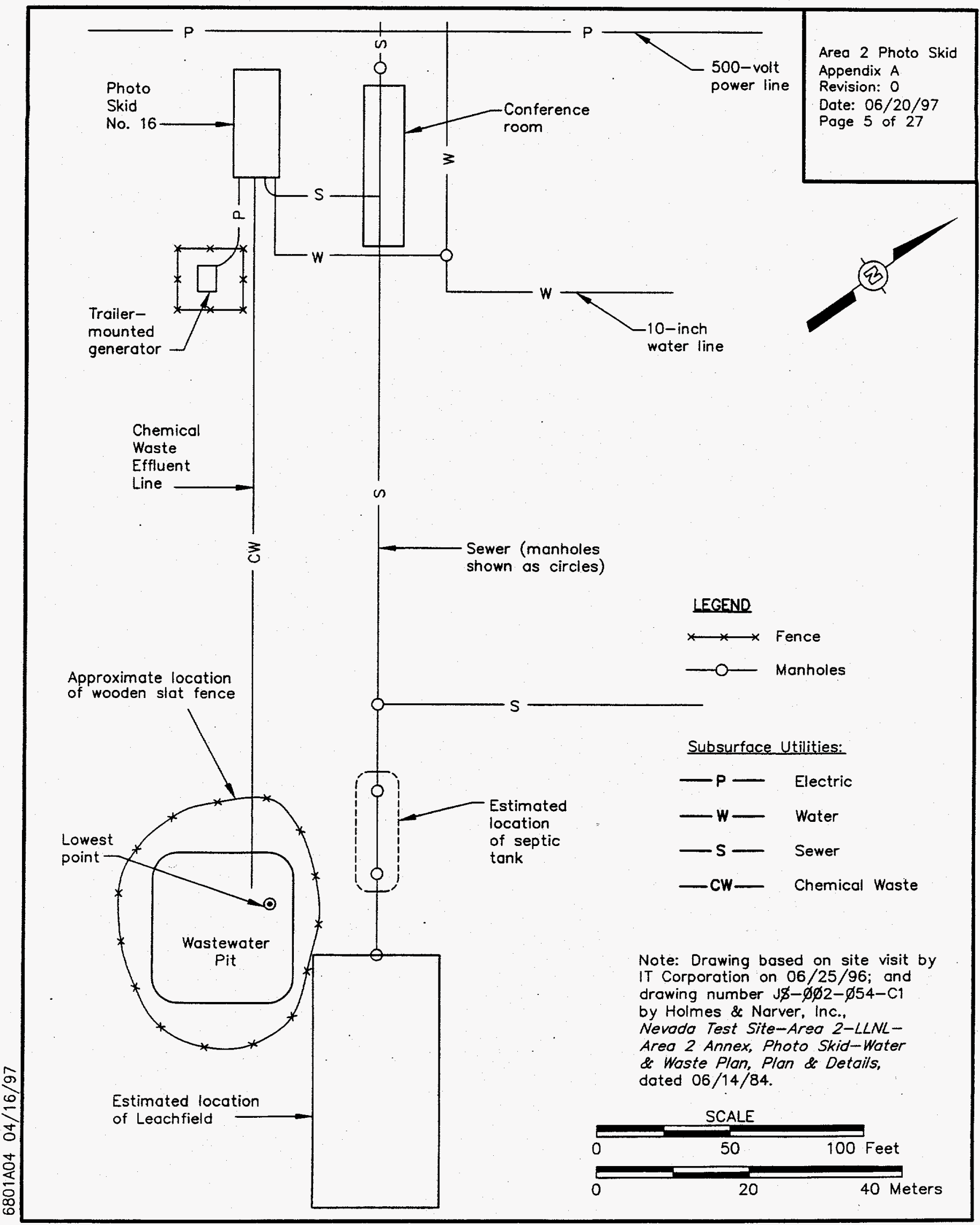

Figure A.1-4

Photo Skid Wastewater Pit Site Map 
Thirteen subsurface samples were collected from four soil borings for analysis of potential COCs. The subsurface samples were selected from sample sets that were collected at continuous sample intervals to a depth of 5.5 meters $(\mathrm{m})$ (18 feet [ft]) below ground surface from each soil boring. Detailed field observations of the surface and subsurface conditions, including lithologic descriptions of soil boring cuttings, were also made during the investigation activities.

\section{A.1.2 Report Content}

This investigation report is divided into four parts:

- Introduction

- Field investigation and sampling activities that describe the site and sampling methodology

- Sample analysis in which the laboratory analytical results are described

- Quality assurance which discusses the precision, accuracy, representativeness, completeness, and comparability of the sample results

To make this investigation report more concise, the following field documentation and laboratory data were not included; however, they are available in the project files and will be available upon request:

- Field Activity Daily Logs

- Sample Collection Logs

- Analysis Requests/Chain-of-Custody forms

- Soil sample descriptions

- Laboratory certificates of analyses

- Headspace and radiological screening results

- Surveillance results

Additional descriptions of the site history, waste inventories, and spill information are discussed in the CAIP (DOE/NV, 1997) for this CAU. 


\section{A.2.0 Field Investigation and Sampling Activities}

Field activities were performed by IT Corporation (IT) on February 18 and 19, 1997. Samples were collected and documented by following approved sampling procedures for field activity documentation, sample collection documentation, decontamination, chain of custody, shipping, and radiation screening protocols (IT, 1994). Field activities were performed in accordance with field sampling instructions as prescribed in the CAIP (DOE/NV, 1997; IT, 1997a) and an approved Site-Specific Health and Safety Plan (IT, 1997b). Quality control (QC) samples (e.g., field blanks, equipment rinsate blanks, trip blanks, and field duplicates) were collected as required by the Industrial Sites Quality Assurance Project Plan (DOE/NV, 1996) and approved procedures (IT, 1994). All field and sample documentation is maintained in project files. During the field activities, waste minimization practices were followed, including segregation of personal protective equipment into bags (based upon daily use) and collection and segregation of the rinsate waters from decontamination operations.

\section{A.2.1 Site Description and Conditions}

The Photo Skid Wastewater Pit CAS is located at the north end of Yucca Flat on the south side of the Area 2 Camp, adjacent to the cable storage yard. The wastewater pit, which is no longer used, is surrounded by a fence (Figure A.2-1).

Topography in the vicinity of the site is nearly level with a slight grade draining to the eastsoutheast. The outer dimensions of the pit are approximately 30 by $30 \mathrm{~m}$ (100 by $100 \mathrm{ft}$ ), and the pit is approximately $2 \mathrm{~m}(7 \mathrm{ft})$ deep at its deepest point. The walls of the pit are steep-sided (25- to 40-degree slopes) except at the corners where the slope is 15 to 20 degrees. The floor is covered with a layer of pebbles and cobbles approximately $91 \mathrm{~cm}$ (36 in.) deep. The aggregate is infiltrated with a coarse sand matrix. Excavation of the aggregate at the outfall pipe found that the sand was very moist at $91 \mathrm{~cm}$ (36 in.), and a chemical odor was noted by a member of the field crew; however, field screening did not indicate the presence of organic vapors.

A survey was also conducted to identify utilities, but none were located in the vicinity of the drilling.

\section{A.2.2 Soil Sampling Logistics}

This section describes the surface and subsurface soil sampling for the Area 2 Photo Skid Wastewater Pit CAS. All samples collected were screened for organic vapors and radiation. 


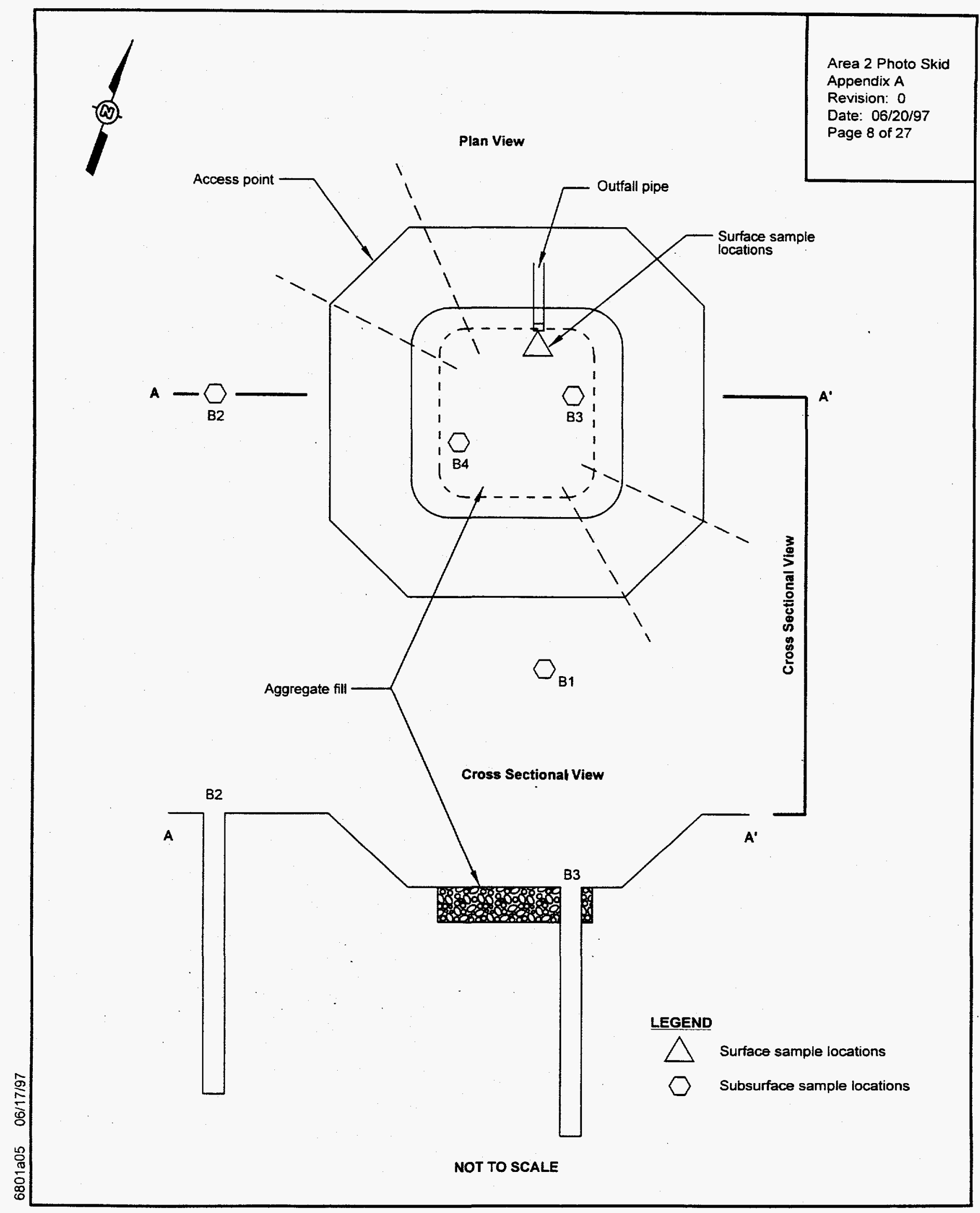

Figure A.2-1 
Field screening yielded no indications of contamination as discussed in the following subsections.

\section{A.2.2.1 Surface Samples}

A surface sample and its duplicate were collected directly below the outfall pipe in the wastewater pit. An attempt to remove the loose surface aggregate to expose in situ soil was not successful because the aggregate was deeper than the anticipated $45 \mathrm{~cm}$ (18 in.). However, because the aggregate's matrix of sands was obviously stained, it was decided to collect the samples at 51- to 61-cm (20- to 24-in.) depths. The gravels and sands in the sample zone were collected in a stainless steel bowl; then the gravels larger than $1.3 \mathrm{~cm}(.5 \mathrm{in}$.) were removed. The remaining materials were placed into appropriate samples bottles. Field screening indicated no contamination.

\section{A.2.2.2 Boring Locations}

Four borings were required to complete the investigation of the Area 2 Photo Skid Wastewater Pit CAS (Figure A.2-1 and attached Boring Logs A-1 through A-4). Two soil borings, B1 and $B 2$, were drilled $3 \mathrm{~m}(10 \mathrm{ft})$ outside of the southeast and southwest sides of the pit, respectively. Both borings were drilled to total depths of $5.5 \mathrm{~m}$ (18 ft). In each boring, two subsurface samples were collected from depths approximately $1.5 \mathrm{~m}(5 \mathrm{ft})$ and $3 \mathrm{~m}(10 \mathrm{ft})$ below the floor of the wastewater pit, which was equivalent to $3.3 \mathrm{~m}(11 \mathrm{ft})$ and $5 \mathrm{~m}(16 \mathrm{ft})$ below ground surface, respectively.

The remaining two borings, B3 and B4, were drilled inside the wastewater pit. The CAIP (DOE/NV, 1997) specified that three discrete samples be collected from each boring, starting at the first encountered soil layer, then at 1.3 to $1.5 \mathrm{~m}(4.5$ to $5.5 \mathrm{ft})$, and finally from the bottom of the boring, 2.4 to $2.8 \mathrm{~m}$ ( 8 to $10 \mathrm{ft}$ ). Additionally, a sample was to be composited from three subsurface soil samples from locations biased towards the highest potential of contamination (Figure A.2-2).

For borings B3 and B4, the aggregate thickness in the pit was $1 \mathrm{~m}(3 \mathrm{ft})$. This meant that the depth of the discrete sample to be collected from the first encountered soil, 1 to $1.5 \mathrm{~m}$ ( 3 to $5 \mathrm{ft}$ ), coincided with the depth of the second specified sample point, 1.3 to $1.5 \mathrm{~m} \mathrm{(4.5}$ to $5.5 \mathrm{ft}$ ). Another sample was collected from 1.5 to $2.1 \mathrm{~m}$ ( 5 to $7 \mathrm{ft}$ ). A sample was then collected from 2.1 to $2.9 \mathrm{~m}$ ( 7 to $9 \mathrm{ft}$ ) to meet the CAIP requirement for a discrete sample from 2.4 to $2.8 \mathrm{~m}$ ( 8 to $10 \mathrm{ft}$ ). Next, a sample was collected from 2.9 to $3.3 \mathrm{~m}$ ( 9 to $11 \mathrm{ft}$ ) for compositing. Finally, 


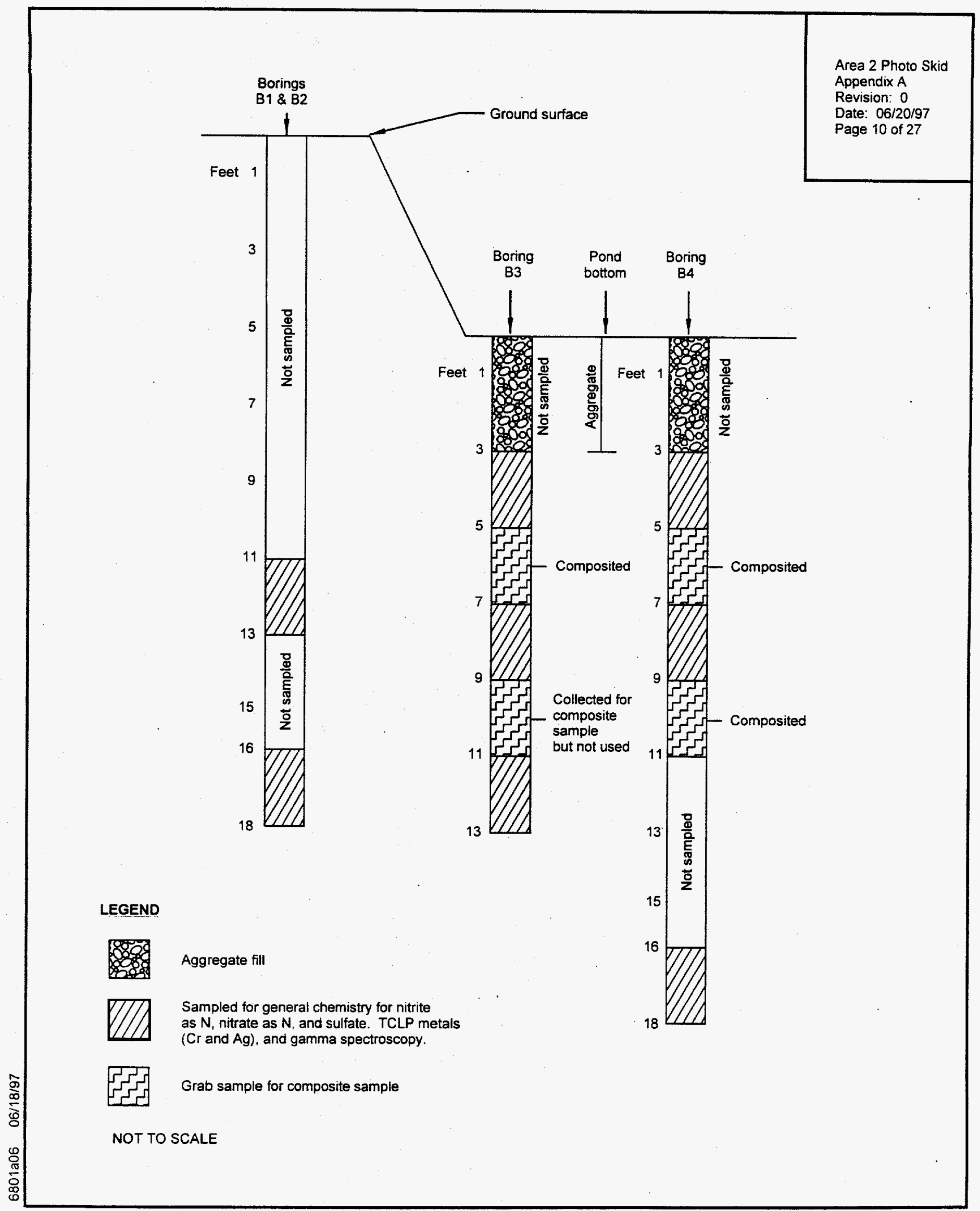

Figure A.2-2

Schematic of Boreholes Drilled at the Wastewater Pit 
in boring B3, a sample was collected from 3.3 to $4.0 \mathrm{~m}$ (11 to $13 \mathrm{ft}$ ) to fulfill the specified three discrete samples required in the CAIP. In boring B4, the sample recovery was prevented due to rocks. A sample was finally collected at 4.9 to $5.5 \mathrm{~m}$ (16 to $18 \mathrm{ft}$ ). See Figure A.2-2 for a graphic representation of these sample intervals.

\section{A.2.2.3 Subsurface Sampling}

Subsurface samples were collected at continuous intervals using a 9-cm (3.5-in.) inside diameter, hollow stem auger with a 6.5-cm (2.5-in.) outside diameter Modified California Sampler with brass sleeves. Each sample was screened for hydrocarbons using a photo ionization detector.

Typical sample collection occurred as follows: A sampling team member decontaminated and assembled the split-spoon sampler and brass sleeves. When the drill bit reached the sampling depth, the Modified California sampler was attached to the 140-pound drive hammer by the sample team member; then the driller ran the sampler to the sample depth. The sampler was driven below the drilled depth with a 64-kilogram (140-pound) hammer with a 79-cm (31-in.) drop to collect the sample. The number of hammer blows required to drive the Modified California sampler for each $15 \mathrm{~cm}$ (6 in.) was recorded. Generally, one-hundred blows for less than $15 \mathrm{~cm}$ ( 6 in.) is considered resistance, although, in some cases, additional blows were specified to maximize sample recovery. The time of sample collection was noted when the sampler was driven to its limit. Finally, the sampler was drilled over to free it from the surrounding formation so it could be brought to the surface.

Once at the surface, a sampling team member removed the Modified California sampler from the hammer and loosened the shoe (the cutting edge of the sampler) and hammer sub (the device that attaches the sampler to the drilling assembly). Then, the sampler was carried to the sampling table located inside a Ryder van. The sampler was then disassembled to remove the $15-\mathrm{cm}$ (6-in.) brass sleeves. The sleeves were collected in the order of deepest to shallowest. For samples that were being collected for volatile analysis, the ends of each brass sleeve were sealed with Teflon ${ }^{\text {TM }}$ sheets and plastic caps. Each cap was annotated with the date, time, and depth of sample collection as well as vertical orientation. The remaining sample was then transferred from the brass sleeve to a decontaminated stainless steel bowl. A portion of the sample was transferred to a ziplock bag for a field-screening check. Then the sample was thoroughly homogenized before being transferred to amber glass sample bottles. All samples were placed on ice immediately following collection. 
Samples were field-screened by placing a portion of each sample into a ziplock bag, closing the bag, and placing the bag into sunlight to warm up for five minutes. After approximately five minutes, a photo ionization detector was used to measure the headspace in the ziplock bag. The reading was recorded in field notes. No field-screening measurements indicated volatiles above instrument background.

\section{A.2.2.4 Geologic Analysis}

As samples were collected, the following soil characteristics were noted: sand and gravel content, relative amounts of pebbles and cobbles, the absence or presence of clays, and any unusual variations. This information was recorded in the field notes and soil boring logs (Attachment A-1) for the project. In addition to a visual description, soil hardness and drilling conditions were also noted.

\section{A.2.2.5 Drilling Characteristics and Subsurface Stratigraphy}

Much of the stratigraphy encountered was medium to very coarse sands with gravels and cobbles. The predominant lithology of the pebbles and cobbles was volcanics. Clay content varied from none to moderate. Samples were usually loose to moderately compacted with low to moderate moisture content.

Soil boring logs and descriptions can be found in Attachment A-1 of this investigation report. 


\section{A.3.0 Sample Analysis}

The analytical results from the soil borings at the Area 2 Photo Skid Wastewater Pit CAU have been compiled and analyzed to determine the presence and/or extent of contamination. The analytical results are summarized in the following sections. Section A.4.0 of this report presents a discussion and summary of quality control samples.

During the drilling and sampling activities, 16 characterization and quality control samples were collected for analysis. A list of the investigation sample numbers (including field duplicate samples) and locations is presented in Table A.3-1. Gaps in the numeric sample sequence represent rinsate, field, trip blanks, and quality control samples and are not included in this table, but are included in Section A.4.2. The complete laboratory result data packages are maintained in project files.

A collected sample was subjected to one of two possible analytical suites. Sampling Suite 1 was the most common regime; all soil samples and field duplicates, with the exception of the composite sample, were analyzed for nitrate as $\mathrm{N}$, nitrite as $\mathrm{N}$, and sulfate; Toxicity Characteristic Leaching Procedure (TCLP) metals of concern for chromium and silver; and gamma spectrometry. Sampling Suite 2 included QC samples such as the rinsates, field blanks, and the composite soil sample. These were analyzed for general chemistry of parameters for nitrate as $\mathrm{N}$, nitrite as $\mathrm{N}$, and sulfate; TCLP method for arsenic, barium, cadmium, chromium, silver, lead, mercury, and selenium; Total Petroleum Hydrocarbons (TPHs) for diesel range; total volatile organic compounds (VOCs); semivolatile organic compounds (SVOCs); and gamma spectrometry.

The sample analysis parameters and laboratory analytical methods for the subsurface soil investigation are presented in Table A.3-2. The sample analytical parameters were selected through the application of the site process knowledge and preliminary sampling according to the U.S. Environmental Protection Agency (EPA) Data Quality Objectives (DQOs) process (EPA, 1994). The results of the DQO process are documented, in part, in the CAIP (DOE/NV, 1997), and the remainder of the documentation is retained in the project files. Samples were analyzed by Lockheed Analytical Services (LAS) in Las Vegas, Nevada. The 
Table A.3-1

Area 2 Photo Skid Wastewater Pit Soil Samples List

\begin{tabular}{|c|c|c|c|c|c|}
\hline $\begin{array}{l}\text { Sample } \\
\text { Number }\end{array}$ & $\begin{array}{c}\text { Sample } \\
\text { Type }\end{array}$ & $\begin{array}{l}\text { Sample } \\
\text { Location }\end{array}$ & $\begin{array}{l}\text { Depth } \\
\text { (ft) }\end{array}$ & $\begin{array}{l}\text { UTM }^{\mathrm{a}} \text { Northing } \\
\text { (NAD83) }\end{array}$ & $\begin{array}{c}\text { UTM Easting } \\
\text { (NAD83) }\end{array}$ \\
\hline SKD00001 & Soil & OUTFALL PIPE & Surface & $N D^{b}$ & ND \\
\hline SKD00002 & Soil-Duplicate & OUTFALL PIPE & Surface & ND & ND \\
\hline SKD00006 & Soil & $\begin{array}{c}\text { B1-OUTSIDE } \\
\text { WASTEWATER } \\
\text { PIT }\end{array}$ & $11-13$ & 6267131.880 & 550175.991 \\
\hline SKD00007 & Soil & $\begin{array}{c}\text { B1-OUTSIDE } \\
\text { WASTEWATER } \\
\text { PIT }\end{array}$ & $16-18$ & 6267131.880 & 550175.991 \\
\hline SKD00008 & Soil & $\begin{array}{c}\text { B2-OUTSIDE } \\
\text { WASTEWATER } \\
\text { PIT }\end{array}$ & $11-13$ & 6267135.597 & 550149.670 \\
\hline SKD00009 & Soil & $\begin{array}{c}\text { B2-OUTSIDE } \\
\text { WASTEWATER } \\
\text { PIT }\end{array}$ & $16-18$ & 6267135.597 & 550149.670 \\
\hline SKD00010 & Soil & $\begin{array}{c}\text { B3-INSIDE } \\
\text { WASTEWATER } \\
\text { PIT }\end{array}$ & $11-13$ & 6267146.486 & 550164.563 \\
\hline SKD00011 & Soil & $\begin{array}{c}\text { B4-INSIDE } \\
\text { WASTEWATER } \\
\text { PIT }\end{array}$ & $3-5$ & 6267139.315 & 550159.777 \\
\hline SKD00012 & Soil & $\begin{array}{c}\text { B4-INSIDE } \\
\text { WASTEWATER } \\
\text { PIT }\end{array}$ & $7-9$ & 6267139.315 & 550159.777 \\
\hline SKD00013 & Soil & $\begin{array}{c}\text { B4-INSIDE } \\
\text { WASTEWATER } \\
\text { PIT }\end{array}$ & $16-18$ & 6267139.315 & 550159.777 \\
\hline SKD00014 & Composite-Soil & $\begin{array}{c}\text { B3 \& B4- } \\
\text { INSIDE } \\
\text { WASTEWATER } \\
\text { PIT }\end{array}$ & $N A^{c}$ & NA & NA \\
\hline SKD00015 & Soil & $\begin{array}{c}\text { B3-INSIDE. } \\
\text { WASTEWATER } \\
\text { PIT }\end{array}$ & $3-5$ & 6267146.486 & 550164.563 \\
\hline SKD00016 & Soil & $\begin{array}{c}\text { B3-INSIDE } \\
\text { WASTEWATER } \\
\text { PIT }\end{array}$ & $7-9$ & 6267146.486 & 550164.563 \\
\hline
\end{tabular}

Universal Transverse Mecator

Non-detect

${ }^{\mathrm{C}}$ Not applicable 
Table A.3-2

Chemical Analytical Methods Used for Wastewater Pit Investigation Samples

\begin{tabular}{|l|l|}
\hline \multicolumn{1}{|c|}{ Analytical Parameter } & \multicolumn{1}{|c|}{ Analytical Method } \\
\hline $\begin{array}{l}\text { General Chemistry Parameters of Concern (Nitrite as N, Nitrate as N, } \\
\text { and Sulfate) }\end{array}$ & EPA $^{\text {a } 300}$ \\
\hline TCLP Metals of Concern ${ }^{\text {b }}$ (Chromium and Silver) & $1311 / 6010$ \\
\hline $\begin{array}{l}\text { TCLP Metals (Arsenic, Barium, Cadmium, Chromium, Lead, Mercury, } \\
\text { Selenium, Silver) }\end{array}$ & $1311 / 6010 / 7000$ \\
\hline Total VOCs & EPA 8260 \\
\hline Total SVOCs & EPA 8270 \\
\hline Total Petroleum Hydrocarbons (diesel) & EPA 8015 (modified) \\
\hline Gamma Spectrometry & LAL-91-SOP-0064 $^{\mathrm{c}}$ \\
\hline
\end{tabular}

\footnotetext{
a U.S. Environmental Protection Agency SW-846 (EPA, 1992)

Toxicity Characteristic Leaching Procedure (EPA, 1992)

¿Lockheed Analytical Services, 1996
}

parameters selected for analysis were based upon the anticipated COCs associated with the activities known to have been conducted at the site (DOE/NV, 1997).

\section{A.3.1 Data Quality Assessment}

The data quality was assessed to determine if the sampling results satisfied the DQOs established in the CAIP (DOE/NV, 1997). The objectives of the sampling were to generate sufficient data to identify the presence of contamination, to assess the extent of contaminant migration, and to determine the appropriate closure recommendation.

The DQOs defined the boundaries of the study area as going from the floor of the wastewater pit to a depth of $30 \mathrm{~cm}$ to $3 \mathrm{~m}$ ( 1 to $10 \mathrm{ft}$ ) below the pit floor. The lateral extent was a $3-\mathrm{m}(10-\mathrm{ft})$ radius around the wastewater pit. The DQOs recognized the following action levels:

- TCLP concentration limits for defining hazardous waste characteristics of solids under Resource Conservation and Recovery Act (RCRA) (Code of Federal Regulations [CFR] 1996, Table 1). These sampling objectives were achieved through field screening and by laboratory analysis. 
- 1,000-milligrams per kilogram (mg/kg) nitrate (as $\mathrm{N}$ ) in soil, $100-\mathrm{mg} / \mathrm{kg}$ nitrite (as $\mathrm{N}$ ) in soil, and 25,000-mg/kg sulfate in soil, per the Nevada Administrative Code (NAC) 445A of 1996, 100 times the groundwater maximum contaminant level (MCL) (NDEP, 1992). Note that only sulfate has a secondary MCL, and there is no MCL for sulfite.

- Isotopic activities or total activities (e.g., total alpha, total beta, or total gamma activities) above the Performance Objective Criteria (POC) set forth by Bechtel Nevada (BN, 1996)

- For any parameters not covered in the above action levels, action levels will be taken from the concentration limits in the proposed RCRA Subpart $\mathrm{S}$ rule for corrective action (Federal Register, v. 55, no. 145, 07/27/90).

- $100-\mathrm{mg} / \mathrm{kg}$ total petroleum hydrocarbons in soil, per the corrective action regulations "Water Pollution Control," Chapter 445A.2272, Section 1(6), (NAC, 1996).

All samples were collected as required by the CAIP (DOE/NV, 1997). Decision rules established by the DQO process and described in the CAIP were used for the decision criteria. A combination of field screening, process knowledge, and the decision criteria was used to supplement and guide the sampling process.

\section{A.3.2 Sample Results}

Soil and quality control samples did not exceed the regulatory action limits established in the DQOs. The sample results for analytes detected are shown on Table A.3-3.

Volatile organic compounds and semivolatile organic compounds were analyzed for samples SKD00003, SKD00005, and SKD00014. Of the VOCs, acetone and 2-butanone were detected in rinsate, field, and trip blanks and are considered common laboratory contaminants. Chloroform was detected at an estimated value below the reporting limit. Semivolatile organic compounds were not detected in any of the samples.

Analysis for nitrate, indicated as $\mathrm{N}$, showed trace readings far below the $1,000-\mathrm{mg} / \mathrm{kg}$ action limit established in the CAIP (DOE/NV, 1997). Soil sample values for nitrate as $\mathrm{N}$ ranged from 1.11 to $89.7 \mathrm{mg} / \mathrm{kg}$. It should be noted that the highest values, 89.7 and $58.6 \mathrm{mg} / \mathrm{kg}$, were detected in samples SKD00001 and SKD00002, respectively. Both samples were collected at the outfall pipe. 
Table A.3-3

Area 2 Photo Skid Wastewater Pit Sample Results - Analytes Detected

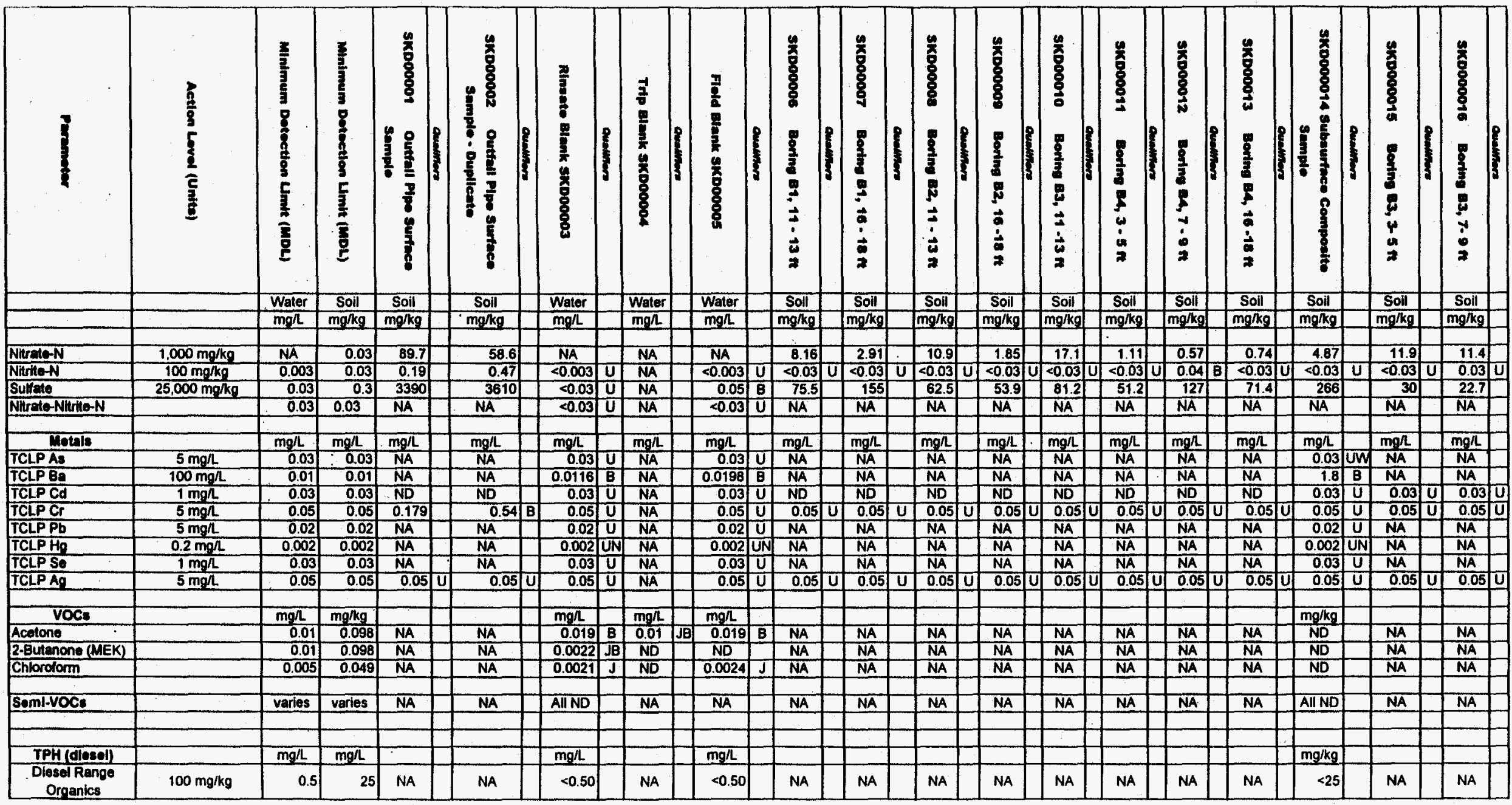

$B=$ Constituent also detected in the blank (organics). Value is less than the CRDL but greater than the 10L (inorganics)

$W=$ Post-digestion spike for GFAA did not meet acceptance criteria and sample absorbance is lass than $50 \%$ of spike absorbance.

$N=$ Matrix spike recovery exceeded accoptance limits inorganics)

$\mathrm{U}=$ Not derecled above the MDL.

ND $=$ Estimated

$N A=$ Not applied or applicable 
Analysis for nitrite (as $\mathrm{N}$ ) showed trace readings far below the $100-\mathrm{mg} / \mathrm{kg}$ action limit established in the CAIP (DOENV, 1997). Soil sample values for nitrite ranged from undetected to $0.47 \mathrm{mg} / \mathrm{kg}$. It should be noted that samples SKD00001 and SKD00002 had concentrations of 0.19 and $0.47 \mathrm{mg} / \mathrm{kg}$, respectively. Both samples were collected at the outfall pipe.

Sulfate levels for all of the soil samples were also well below the $25,000-\mathrm{mg} / \mathrm{kg}$ action level. Values ranged from 30 to $3,610 \mathrm{mg} / \mathrm{kg}$. The two highest values were 3,390 and $3,610 \mathrm{mg} / \mathrm{kg}$ for samples SKD00001 and SKD00002, respectively. Samples SKD00005 and SKD00016 had 'B' qualifiers indicating that the reported values were less than the contract-required detection limit, but were greater than or equal to the instrument detection limit.

All samples were analyzed for the toxicity characteristics of chromium and silver. Samples SKD00001 and SKD00002 showed traces of chromium (0.179 and 0.54 milligrams per liter [mg/L]) at concentrations well below the action level of $5 \mathrm{mg} / \mathrm{L}$. Sample SKD00002 had a 'B' qualifier that indicates the reported value was less than the contract-required detection limit, but was greater than or equal to the instrument detection limit. All other samples were non-detects.

Samples SKD00014 (a composite soil sample), SKD00003 (a rinsate blank), and SKD00005 (a field blank) were all analyzed for the complete suite of TCLP RCRA metals. Trace $(<1.8 \mathrm{mg} / \mathrm{L})$ amounts of barium were detected, but did not exceed the $100-\mathrm{mg} / \mathrm{L}$ action level. Each detected barium value had an associated 'B' qualifier (see Table A.3-3).

Radionuclides detected in water and surface samples were all of primordial origin or their decay products. All sample concentrations were within the normal range of background and below the levels established in the POC (BN, 1996). Background field-screening readings were approximately 200 counts per minute. 


\section{A.4.0 Quality Assurance}

The quality assurance (QA) and QC results for the investigation sampling activities at the Area 2 Photo Skid Wastewater Pit CAU No. 332 are summarized in the following text. Also included is a discussion about measurement of the QA and QC objectives and documentation of nonconformances. Detailed information about the QA program for this sampling event is contained in the Industrial Sites QAPP (DOE/NV, 1996).

\section{A.4.1 Quality Control Samples}

QC samples were collected and analyzed throughout the Area 2 Photo Skid Wastewater Pit sample collection process. A list of collected field QC samples is presented in Table A.4-1. A field blank, an equipment rinsate blank, a trip blank, and a field duplicate were collected for analysis to send to an off-site laboratory. Field blanks were taken by placing distilled water into appropriate sample bottles under the same field conditions as the environmental samples and preserving them according to the requirements specified in the Industrial Sites QAPP (DOE/NV, 1996). Equipment rinsate blanks were obtained by pouring distilled water over the decontaminated sampling equipment into the appropriate sample bottles, and by preserving it, as applicable. The results of the QC samples are discussed in the following sections.

Table A.4-1

Area 2 Photo Skid Wastewater Pit Field Quality Control Samples Collected for Laboratory Analysis

\begin{tabular}{|c|c|c|}
\hline Sample Number & Sample Type & Notes \\
\hline \hline SKD00002 & Field duplicate & Sampling-effect sample \\
\hline SKD00003 & Equipment blank & Sampling equipment \\
\hline SKD00004 & Trip blank & Environmental-effect sample \\
\hline SKD00005 & Field blank & Environmental-effect sample \\
\hline
\end{tabular}




\section{A.4.1.1 Field Quality Control Samples}

Review of the field blank analytical data for the investigation sampling indicates that crosscontamination from field methods did not occur during sample collection. The field blanks were analyzed for the parameters listed in Table A.3-2, and no COCs were identified above the laboratory method detection limits.

During the sampling event, a field duplicate (SKD00002) was collected with SKD00001 at the outfall pipe and analyzed for the site investigation parameters listed in Table A.3-2. Results for SKD00002 agreed satisfactorily with the results of SKD00001. The field duplicate sampling results for SKD00002, like SKD00001, did not detect COCs above action levels.

A review of the analytical data for the field, trip, and rinsate blanks (Table A.3-2) indicates that the Area 2 Photo Skid Wastewater Pit soil samples were not contaminated during field activities or shipment. Cross-contamination due to inadequate equipment decontamination did not occur. Volatile organic compounds such as acetone, 2-butanone, and chloroform were found in trace amounts in the field and equipment blanks, and acetone was found in the trip blank. These VOCs, in low concentrations, are considered common lab contaminants and are not indicative of field or transport contamination problems.

\section{A.4.1.2 Laboratory Quality Control Samples}

Analysis of method QC blanks and laboratory control samples was performed for each parameter analyzed by LAS. Laboratory duplicate and matrix spike/matrix spike duplicate analyses were performed on control samples and samples from the investigation activities. In general, the laboratory duplicate results were considered to be in agreement with the environmental sample results. The complete $\mathrm{QC}$ sample results are maintained in the project files.

\section{A.4.2 Quality Assurance Objectives Measurements}

The QA objectives ensure that the analytical data collected are meaningful, defensible, and useable for the desired purposes. Measurement of specific QA objectives is discussed in the following sections. 


\section{A.4.2.1 Precision}

Precision is a quantitative measure of the variability of a group of measurements from their average value. Additional information regarding the measurement of precision may be found in the Industrial Sites QAPP (DOE/NV, 1996). Precision is assessed by creating, analyzing, and comparing laboratory duplicates from one or more field samples. It is reported as relative percent difference (RPD) which is calculated as the difference between the measured concentrations of duplicate samples, divided by the average of the two concentrations, and multiplied by 100 . For the subsurface soil sampling project, the accepted precision goals for the off-site laboratory analyses are specified in the Industrial Sites QAPP (DOE/NV, 1996) and are listed in Table A.4-2 which also presents the results of precision measurement for the Area 2 Photo Skid Wastewater Pit soil sampling data. The table lists the total number of RPD precision measurements by analysis type, the acceptable (i.e., target) RPD range per the Industrial Sites QAPP (DOE/NV, 1996), and the number and percent of RPD precision measurements within the acceptance range.

All RPD measurements, with the exception of nitrite and nitrate, were within the established laboratory precision limits (see Table A.4-2).

A variation occurred between the nitrate and nitrite values for sample SKD00001 and its field duplicate SKD00002. This resulted in the target range for the precision RPD being exceeded. This is not unusual since variabilities exist between field samples due to soil heterogeneities. Therefore, the variation is considered acceptable.

Another difference occurred for the analyte barium between the results of sample SKD00003 and its laboratory duplicate. Sample SKD00003 (11.6 micrograms per liter $[\mu \mathrm{g} / \mathrm{L}])$ and its split SKD00003D $(19.8 \mu \mathrm{g} / \mathrm{L})$ are well below the detection limit of $200 \mu \mathrm{g} / \mathrm{L}$. Therefore, the slight variation in the results is expected, is considered "noise," and is acceptable.

\section{A.4.2.2 Accuracy}

Analytical accuracy is defined as the nearness of a measurement to the true or accepted reference value. It is the composite of the random and systematic components of the measurement system and determines bias in a measurement system. The random component of accuracy is measured 
Table A.4-2

Laboratory Precision Measurements for Area 2 Photo Skid Wastewater Pit Subsurface Soil Sampling Data

\begin{tabular}{|c|c|c|c|c|c|c|c|}
\hline \multirow[b]{2}{*}{ Parameter } & \multicolumn{6}{|c|}{ Laboratory Duplicate Totals } & \multirow[b]{2}{*}{ Total } \\
\hline & $\begin{array}{l}\text { General Chem } \\
\text { for Nitrite, } \\
\text { Nitrate, and } \\
\text { Sulfate }\end{array}$ & $\begin{array}{c}\mathrm{TC}^{\mathrm{a}} \mathrm{RCRA}^{\mathrm{b}} \\
\text { Metals }\end{array}$ & $\begin{array}{l}\text { Total } \\
\text { vocs }\end{array}$ & $\begin{array}{l}\text { Total } \\
\text { svOCs }\end{array}$ & $\underset{\text { Diesel }^{\mathrm{TPH}}}{\mathrm{T}}$ & $\begin{array}{l}\text { Gamma } \\
\text { Spec }^{e}\end{array}$ & \\
\hline $\begin{array}{l}\text { Total Number of } \\
\text { RPD' Precision } \\
\text { Measurements }\end{array}$ & 8 & 8 & 9 & 22 & 2 & 3 & 52 \\
\hline $\begin{array}{l}\text { Actual Range of } \\
\text { Precision RPD } \\
\text { Results }\end{array}$ & $0-85$ & $0-52$ & $0-3.5$ & $0-39$ & $0-29$ & $0-17$ & $N A^{Q}$ \\
\hline $\begin{array}{l}\text { Target Range for } \\
\text { Precision RPD }\end{array}$ & $0-20$ & $0-20$ & $0-24$ & $0-50$ & $0-40$ & $0-20$ & NA \\
\hline $\begin{array}{l}\text { Number of Precision } \\
\text { RPD Measurements } \\
\text { within Target Range }\end{array}$ & 6 & 7 & 9 & 22 & 2 & 3 & 49 \\
\hline $\begin{array}{l}\text { Percent of Precision } \\
\text { RPD Measurements } \\
\text { within Target Range }\end{array}$ & 75 & 87.5 & 100 & 100 & 100 & 100 & 94 \\
\hline
\end{tabular}

\footnotetext{
${ }^{a}$ Toxicity Characteristic

${ }^{b}$ Resource Conservation and Recovery Act (CFR, 1996)

Volatile organic compound(s)

Total petroleum hydrocarbon - diesel range
}

\author{
Gamma Spectrometry \\ Relative percent difference \\ ${ }^{9}$ Not applicable \\ ${ }^{h}$ As per the Industrial Sites QAPP (DOE/NV, 1996)
}

and documented through the analyses of spiked samples. Sampling accuracy is assessed by evaluating the results of spiked samples and laboratory control samples. Accuracy measurements are calculated as percent recovery by dividing the measured sample concentration by the true concentration and multiplying the quotient by 100 .

The target accuracy ranges established for the subsurface soil samples analyzed by the laboratory and the actual accuracies achieved are shown in Table A.4-3 for both matrix spike and laboratory control samples. Based on the results shown in this table, 99 percent of all QC sample recoveries were within the acceptable limits, which indicates excellent analytical accuracy. Additional information about measurement of accuracy for these samples is found in 
Table A.4-3

Laboratory Accuracy Measurements for

\section{Area 2 Photo Skid Wastewater Pit Subsurface Soil Sampling Data}

\begin{tabular}{|c|c|c|c|c|c|c|}
\hline \multirow[b]{2}{*}{ Parameter } & \multicolumn{5}{|c|}{ Analysis } & \multirow[b]{2}{*}{ Total } \\
\hline & $\begin{array}{l}\text { General Chem for } \\
\text { Nitrite, Nitrate, } \\
\text { and Sulfate }\end{array}$ & $\begin{array}{l}\text { TC }^{a} \text { RCRA }^{b} \\
\text { Metals }\end{array}$ & Total Vocs ${ }^{c}$ & Total SVOCs & TPH Diesel $^{d}$ & \\
\hline Total Number of $\% \mathrm{R}^{\mathrm{e}}$ Measurements & 18 & 16 & 30 & 55 & 5 & 124 \\
\hline $\begin{array}{l}\text { Matrix Spike Samples (range of } \\
\text { actual \%R) }\end{array}$ & $84-101$ & $55-122$ & $87-94$ & $27-114$ & $104-105$ & $N A^{f}$ \\
\hline $\begin{array}{l}\text { Laboratory Control Samples (range of } \\
\text { actual \%R) }\end{array}$ & $94-100$ & $85-119$ & $84-99$ & $50-101$ & $101-135$ & NA \\
\hline$\%$ R Target Range (Soil) ${ }^{9}$ & $80-120^{h}$ & $80-120$ & $37-160$ & $10-230$ & $61-144$ & NA \\
\hline $\begin{array}{l}\text { Number of \%R Measurements within } \\
\text { the Target Range }\end{array}$ & 18 & 14 & 30 & 55 & 5 & 123 \\
\hline $\begin{array}{l}\text { Percent of \%R Measurements within } \\
\text { the Target Range }\end{array}$ & 100 & 87.5 & 100 & 100 & 100 & 99 \\
\hline
\end{tabular}

${ }^{a}$ Toxicity characteristic

Resource Conservation and Recovery Act (CFR, 1996)

Volatile organic compound(s)

Total petroleum hydrocarbons - diesel range

Percent recovery

Not applicable

As per the Industrial Sites QAPP (DOE/NV, 1996)

Laboratory-established value 
the Industrial Sites QAPP (DOE/NV, 1996). Parameter-specific accuracy (percent recovery) measurements may be found in the laboratory analytical report data package maintained in the project files.

Field accuracy is assessed by confirming that the documents of record track the sample from its origin, through transfer of custody, to its disposal. The goal of field accuracy is for all samples to be collected from the correct locations at the correct time, placed in a correctly labeled container with the correct preservative, and sealed with custody tape to prevent tampering.

Any deviations from these requirements must be documented and explained, and the related data must be qualified accordingly. During the Area 2 Photo Skid Wastewater Pit sampling project, all field accuracy goals were met.

\section{A.4.2.3 Representativeness}

Representativeness expresses the degree to which sample data accurately and precisely represent a characteristic of a population, parameter variations at a sampling point, or an environmental condition (EPA, 1987). Sample representativeness is achieved through the implementation of a sampling program designed to ensure proper sampling locations, collection of the appropriate number of samples, and the use of validated analytical methods. Representativeness may also be assessed through analysis of duplicate samples.

The Area 2 Photo Skid Wastewater Pit subsurface soil sampling project identified the COCs present in the soils and accurately and precisely quantified their concentrations. Samples were collected from predetermined intervals; collection and analysis were performed in accordance with approved procedures (IT, 1994); and both field and laboratory duplicates were analyzed. As a result, the Area 2 Photo Skid Wastewater Pit soil sampling data may be qualified as representative of site-specific environmental conditions. Additional information about the measurement of representativeness is found in the Industrial Sites QAPP (DOE/NV, 1996).

\section{A.4.2.4 Completeness}

Completeness is defined as a percentage of measurements made that are judged to be valid. In general, the Area 2 Photo Skid Wastewater Pit subsurface soil sampling data exhibit a high degree of completeness. The subsurface soil sampling and analytical program was executed in 
accordance with the field sampling instructions (IT, 1997a) and associated Records of Technical Change available upon request from project files. The specified sampling intervals were used as planned with the exception of a downward shift in some sample depths because of the unexpected gravel thickness. All specified samples were collected, and all sample containers reached the laboratory intact and properly preserved (if applicable). For all samples, sample temperature was maintained during shipment to the laboratory, and sample chain of custody was maintained during sample storage and shipment.

\section{A.4.2.5 Comparability}

Comparability is a qualitative parameter expressing the confidence with which one dataset can be compared to another (EPA, 1987). A standardized sampling approach and analytical methodology are used to achieve data comparability. To ensure comparability, all Area 2 Photo Skid Wastewater Pit field and laboratory activities were performed and documented in accordance with approved procedures (e.g., IT, 1994). Approved, standardized methods and procedures were also used to analyze and report the data (e.g., EPA, 1992). This approach ensured that the data from this project can be compared to other datasets.

\section{A.4.3 Field Deficiencies/Nonconformance}

No field deficiencies or nonconformances occurred during the sampling activities at the wastewater pit.

\section{A.4.4 Laboratory Nonconformances}

Laboratory nonconformances are generally due to inconsistencies in analytical instrumentation operation and fluctuations in internal standard and calibration results. A laboratory nonconformance was noted during analysis of the Area 2 Photo Skid Wastewater Pit samples. For VOC analysis, Method 8240 (EPA, 19.92) was requested. The laboratory ran a Method 8260 (EPA, 1992) instead. Method 8260 analytical parameters are the same as those of Method 8240, but some additional analytes are given. The 8260 Method does not affect the final results and reports the results with better detection limits than Method 8240. The noted nonconformance did not affect the overall quality of the sampling event results. Laboratory and validation data qualifiers (if applicable) were assigned to identify those isolated samples that may have had the data quality impacted. The laboratory data packages which detail nonconformances are maintained in the project files. 


\section{A.5.0 References}

BN, see Bechtel Nevada.

Bechtel Nevada. 1996. Nevada Test Site Performance Objective for Certification of Nonradioactive Hazardous Waste. Las Vegas, NV.

CFR, see Code of Federal Regulations.

Code of Federal Regulations. 1996. 40 CFR 261.24. "Toxicity Characteristic, Environmental Protection Agency." Washington, DC: U.S. Government Printing Office.

DOE/NV, see U.S. Department of Energy, Nevada Operations Office.

EG\&G/EM, see EG\&G Energy Measurements, now Bechtel Nevada.

EG\&G/EM. 1993. Aerial photo number 7427-04 \#2, Photo Skid Wastewater Pit.

Las Vegas, NV: EG\&G/EM Remote Sensing Laboratory.

EPA, see U.S. Environmental Protection Agency.

FFACO, see Federal Facility Agreement and Consent Order.

Federal Facility Agreement and Consent Order of 1996. Agreed to by the Nevada Division of Environmental Protection, the U.S. Department of Energy, and the U.S. Department of Defense.

Federal Register. 1990. FR 55145. Washington, DC: U.S. Government Printing Office.

H\&N, see Holmes and Narver, Inc.

Holmes and Narver, Inc. 1984. Nevada Test Site - Area 2 - LLNL - Area 2 Annex, Photo SkidWater and Waste Plan, Plan and Details, Drawing Number JS-002-054-C1. Las Vegas, NV.

IT, see IT Corporation.

IT Corporation. 1994. Standard Quality Practices. Las Vegas, NV.

IT Corporation. 1997a. "Field Instruction for Corrective Action Investigation at the Area 2 Photo Skid Wastewater Pit." Las Vegas, NV. 
IT Corporation. 1997b. Site Specific Health and Safety Plan, Area 2 Photo Skid Wastewater Pit. Las Vegas, NV.

Lockheed Analytical Laboratory, see Lockheed Analytical Services (LAS).

Lockheed Analytical Services (LAS). 1996. “Sample preparation and analysis for gamma activity in solids," Lockheed Analytical Laboratory (LAL), LAL-91-SOP-0064. In the LAS books of Standard Operating Procedures, Control Copy No. 16. Las Vegas, NV.

NAC, see Nevada Administrative Code.

NDEP, see Nevada Division of Environmental Protection.

Nevada Administrative Code. 1996. "Water Controls," NAC 445A. Carson City, NV.

Nevada Division of Environmental Protection. 1992. "Contaminated Soil and Groundwater Remediation Policy." Carson City, NV.

U.S. Department of Energy, Nevada Operations Office. 1996. Industrial Sites Quality Assurance Project Plan, Nevada Test Site, Nevada, DOE/NV--372. Las Vegas, NV.

U.S. Environmental Protection Agency. 1987. Data Quality Objectives for Remedial Response Activities, EPA/540/G-87-003. Washington, DC.

U.S. Environmental Protection Agency. 1992. Test Methods for Evaluating Solid Waste, Physical/Chemical Methods, SW-846, $3^{\text {rd }}$ edition with updates. Washington, DC.

U.S. Environmental Protection Agency. 1994. Guidance for the Data Quality Objectives Process, EPA QA/G-4. Washington, DC.

U.S. Department of Energy, Nevada Operations Office. 1997. Corrective Action Investigation Plan: Area 2 Photo Skid No. 16 Wastewater Pit, Corrective Action Unit 332, Nevada Test Site, Rev. 1. Las Vegas, NV. 
Area 2 Photo Skid

Attachment 1

Revision: 0

Date: 06/20/97

Page 1 of 5

\section{Attachment 1}

\section{Boring Logs}




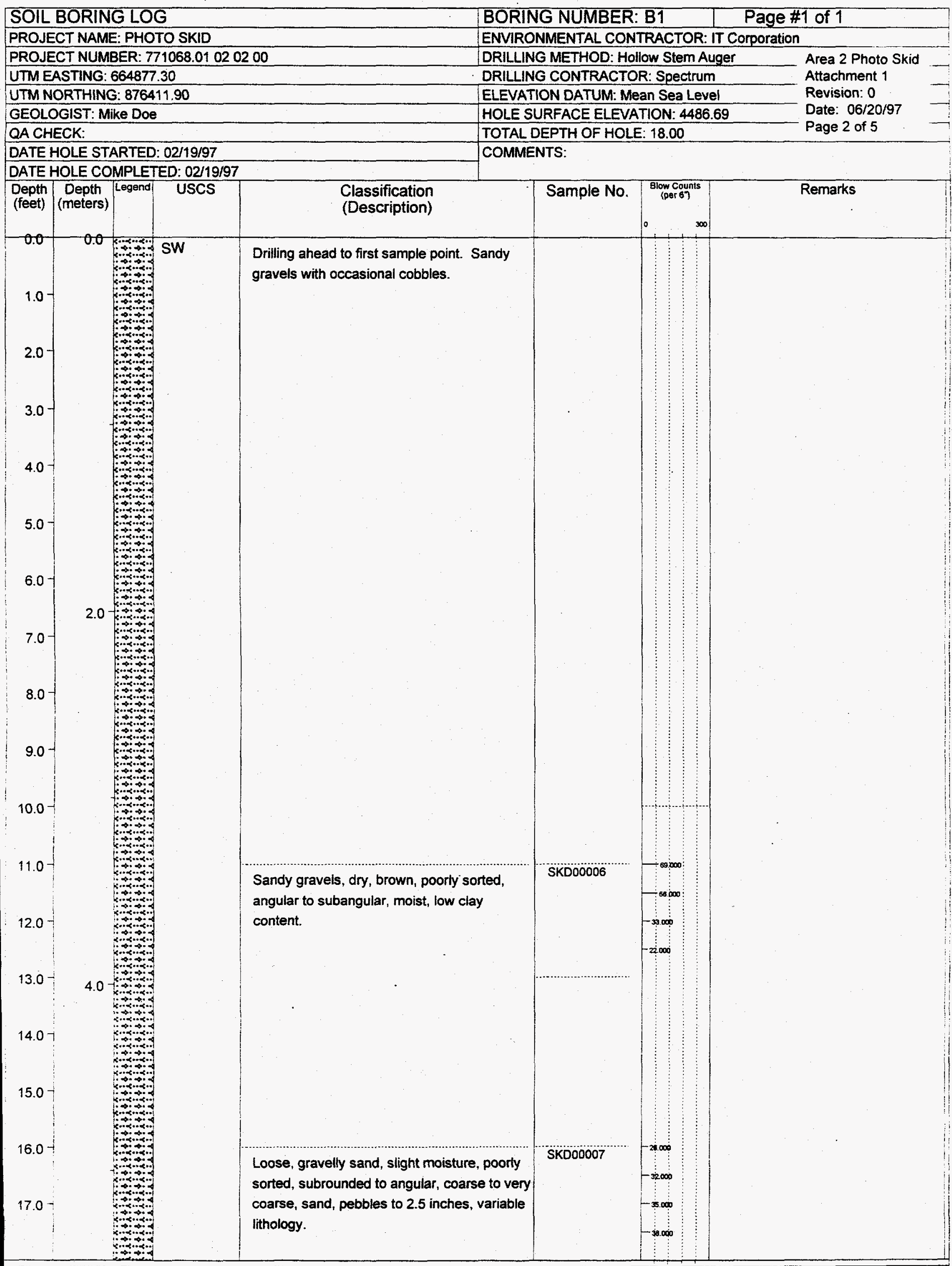




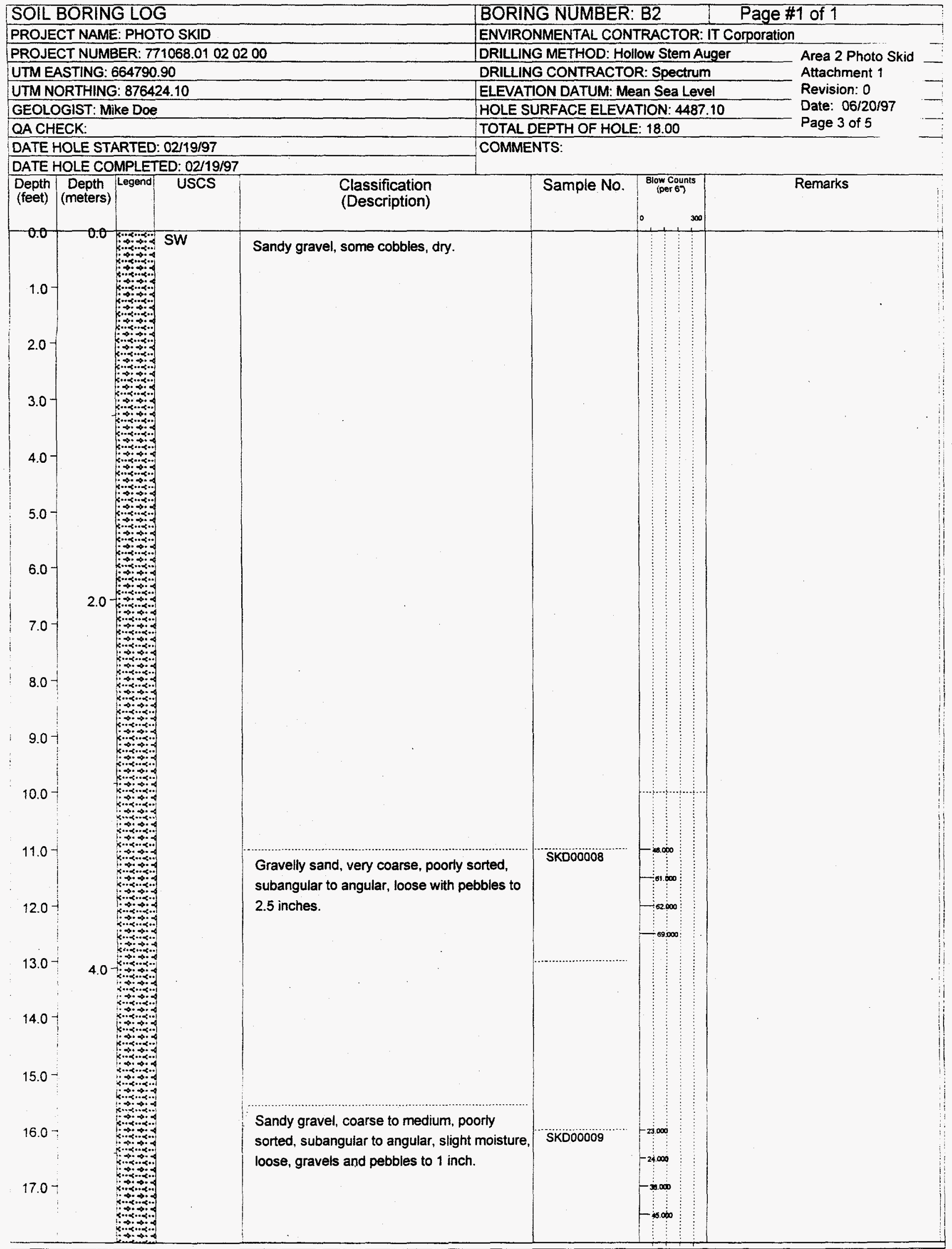




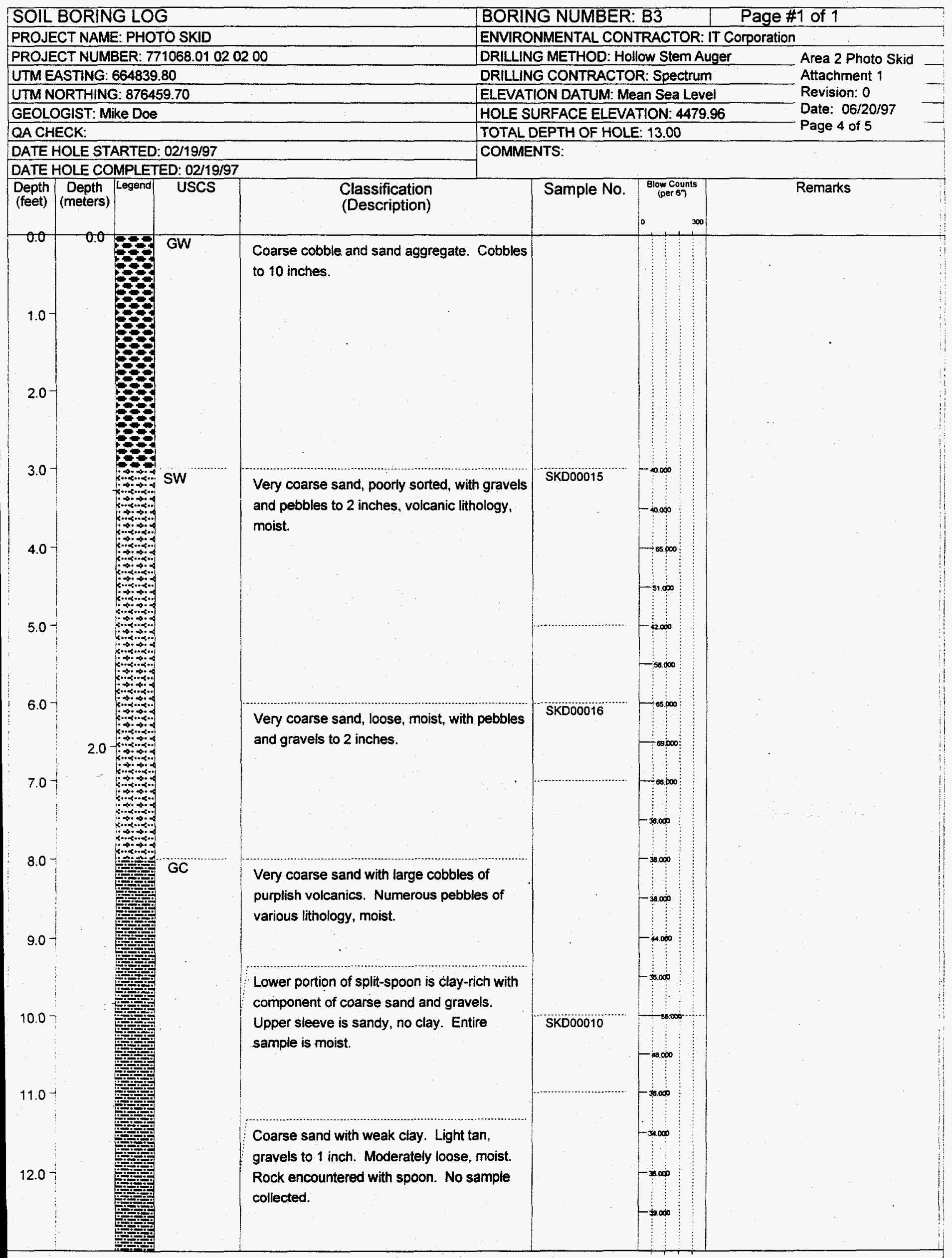




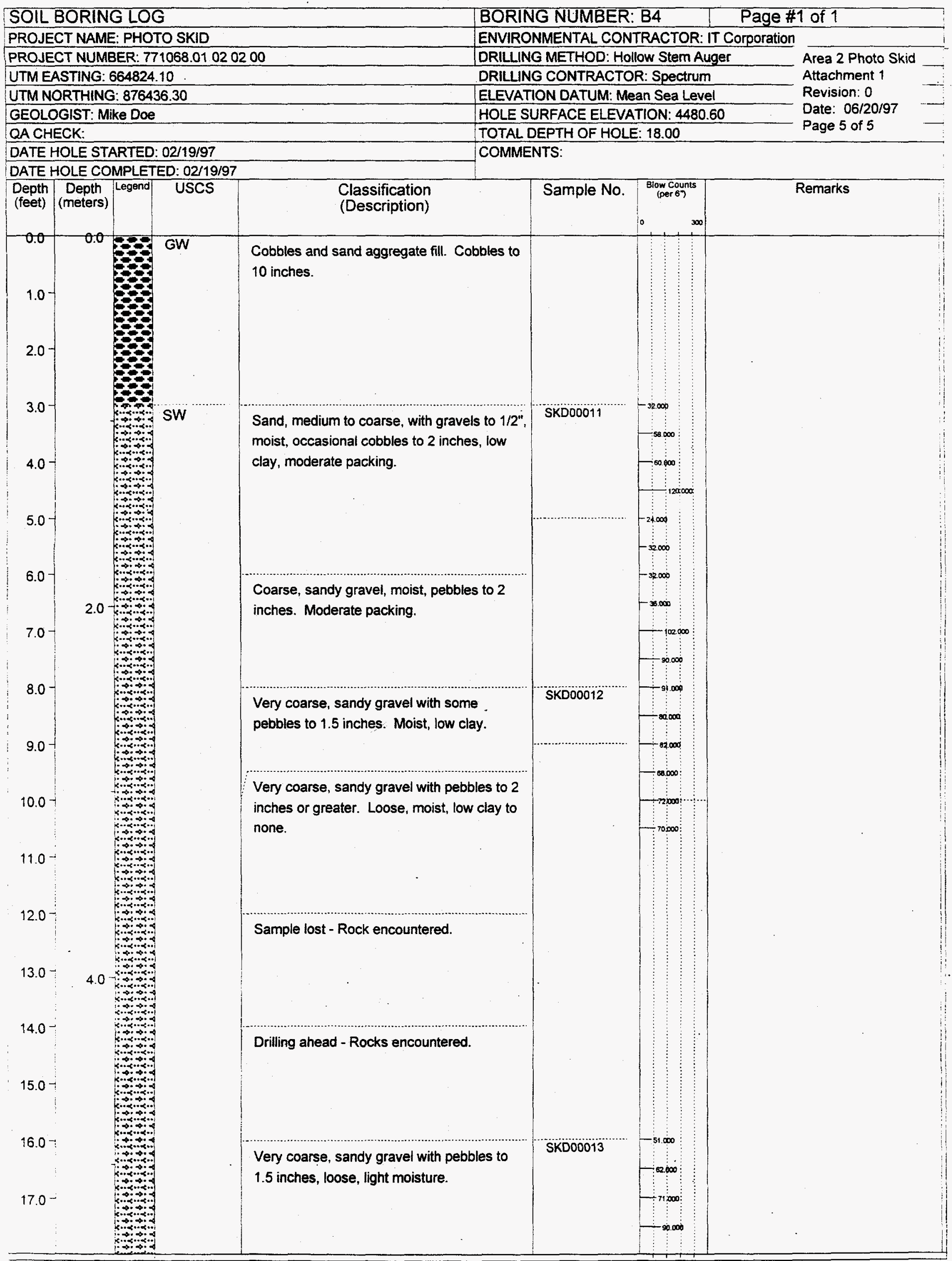


Area 2 Photo Skid

Appendix B

Revision: 0

Date: $06 / 20 / 97$

Page 1 of 4

\section{Appendix B}

\section{Document Review Sheet}




\section{NEVADA ENVIRONMENTAL RESTORATION PROJECT DOCUMENT REVIEW SHEET}

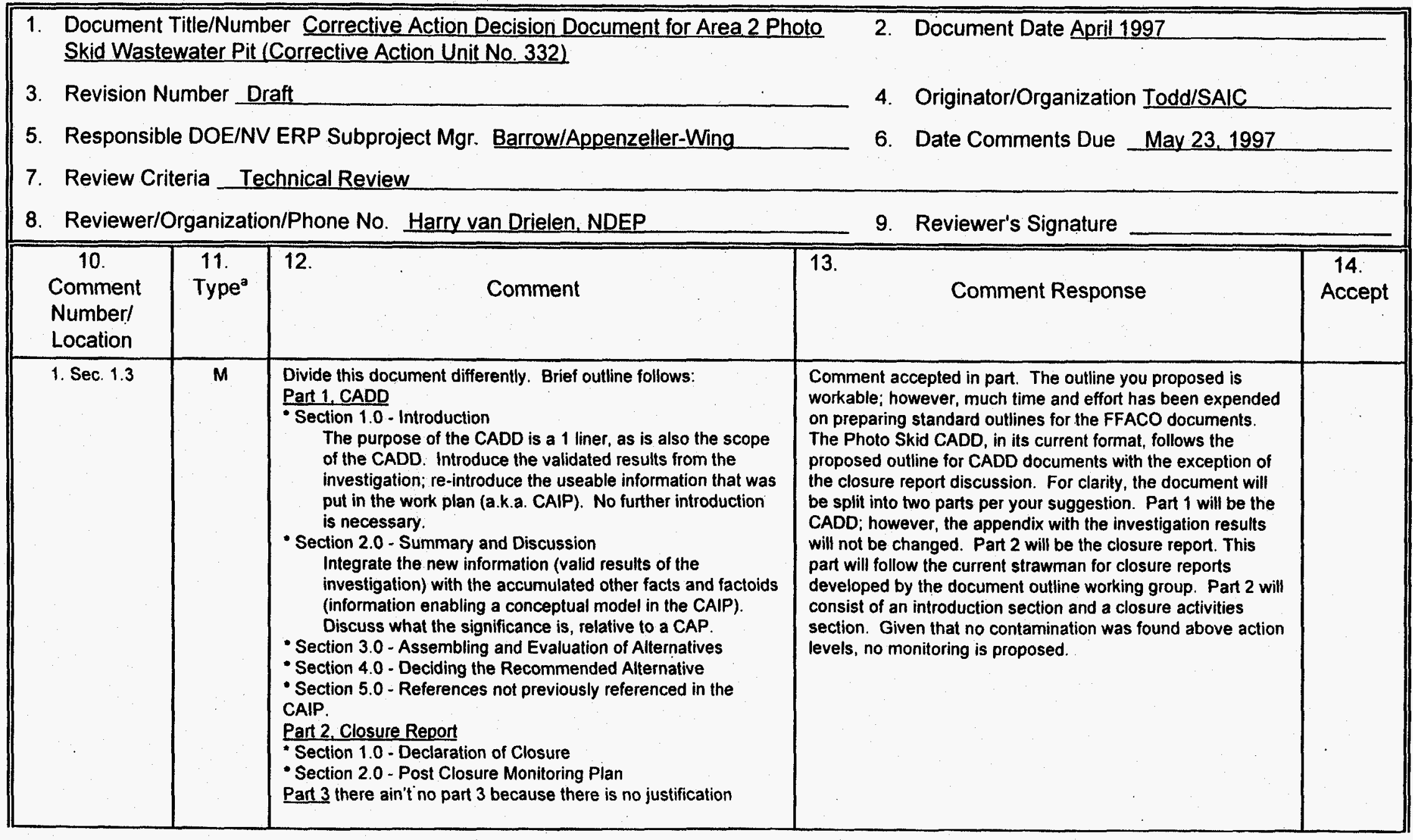




\section{NEVADA ENVIRONMENTAL RESTORATION PROJECT DOCUMENT REVIEW SHEET}

Document Title/Number Corrective Action Decision Document for Area 2 Photo Skid

Revision Number Draft Wastewater Pit (Corrective Action Unit No. 332)

Reviewer/Organization Harry van Drielen, NDEP

\begin{tabular}{|c|c|c|c|c|}
\hline $\begin{array}{l}10 . \\
\text { Comment } \\
\text { Numberl } \\
\text { Location }\end{array}$ & $\begin{array}{c}11 . \\
\text { Type }^{a}\end{array}$ & Comment & Comment Response & $\begin{array}{c}14 . \\
\text { Accept }\end{array}$ \\
\hline 2. Sec. 2.2 & $\mathbf{M}$ & $\begin{array}{l}\text { The first sentence introduces Appendix A, the reservoir for } \\
\text { "corrective action investigation results." Appendix A may be } \\
\text { that, but it also has the kitchen sink. This section on } \\
\text { Investigation Results must affirm that only validated results are } \\
\text { included in the CADD, no junk results. Those credible, useable } \\
\text { results are the corporis majorem of the CADD, not to be stuck } \\
\text { off in some appendix. An appendix to a Closure Report sounds } \\
\text { suspiciously like failure to integrate the good and eliminate the } \\
\text { bad; just because good money is spent doesn't mean that the } \\
\text { consequences of expenditure deserve to be accounted by } \\
\text { stuffing an appendix with unessentials. } \\
\text { This CADD/CR is a } 2 \text { part document (see brief outline). Part } 1 \text { is } \\
\text { the CADD. Part } 2 \text { is the CR. Eliminate the appendix (is an } \\
\text { appendix A, then there is also a B, otherwise, it is just an } \\
\text { appendix, not Appendix A). Tabulate the useful, valid data in } \\
\text { Part } 1 \text { and then use the data to buttress the DECISION, which is } \\
\text { that the Photo Skid waste water disposal basin ain't got no } \\
\text { contamination that merits action. Throw some words in that a } \\
\text { CAP is not required, but that the basin will be filled in a manner } \\
\text { to make it harmonious with its community. Part } 2 \text { then is a one } \\
\text { pager, announcing that the site has been investigated, that } \\
\text { nothing was found that requires attention, that the site is } \\
\text { effectively closed, and that no further action is required, but the } \\
\text { DOE GOOD GUYS will monitor anyway. }\end{array}$ & $\begin{array}{l}\text { Comment accepted in part. The format of the document will } \\
\text { be changed as discussed in the response to the first } \\
\text { comment. A brief discussion of the housekeeping-type } \\
\text { activity will be included; however, the text will clearly indicate } \\
\text { that this action is for good management purposes and is not a } \\
\text { corrective action. Monitoring of the site is not proposed. }\end{array}$ & \\
\hline
\end{tabular}




\section{NEVADA ENVIRONMENTAL RESTORATION PROJECT DOCUMENT REVIEW SHEET}

Document Title/Number Corrective Action Decision Document for Area 2 Photo Skid

Revision Number Draft Wastewater Pit (Corrective Action Unit No. 332)

Reviewer/Organization Harry van Drielen. NDEP

\begin{tabular}{|c|c|c|c|c|}
\hline $\begin{array}{l}10 . \\
\text { Comment } \\
\text { Numberl } \\
\text { Location }\end{array}$ & $\begin{array}{l}11 . \\
\text { Type }^{a}\end{array}$ & Comment & Comment Response & $\begin{array}{c}14 . \\
\text { Accept }\end{array}$ \\
\hline 3. Appendix A & $M$ & $\begin{array}{l}\text { Eliminate pages } i, i i, \text { ii, iv, } v, \text { vi, and vii, the page with } \\
\text { acronyms/abbreviations, and all of Section A1.0 through A1.2. } \\
\text { Integrate Section A2.0 and Section } 3.0 \text { and Section } 4.0 \text { into part } \\
1 \text {, Section } 2 \text {, and edit with a vengeance. Transfer Section A } 5.0 \\
\text { onto Part } 1 \text {, Section } 5.0 \text { and delete all referenced which are in } \\
\text { the CAIP. Move the Boring Logs (valuable information should } \\
\text { not be in an appendix) to Part } 1 \text {, Section } 2.0 \text {. } \\
\text { All of this change makes Part } 1 \text {, Section } 2.0 \text { very bulky, as it } \\
\text { should be, since it is the guts of the decision machinery. Get all } \\
\text { the important eggs tightly packaged in one basket. }\end{array}$ & $\begin{array}{l}\text { Comment noted. Please see responses to previous } \\
\text { comments. } \\
\text {. }\end{array}$ & \\
\hline
\end{tabular}

